\title{
WestVirginiaUniversity
}

THE RESEARCH REPOSITORY @ WVU

Graduate Theses, Dissertations, and Problem Reports

2017

\section{Marriage and Textiles in the American Civil War South}

\author{
Hannah McClearnen
}

Follow this and additional works at: https://researchrepository.wvu.edu/etd

\section{Recommended Citation}

McClearnen, Hannah, "Marriage and Textiles in the American Civil War South" (2017). Graduate Theses, Dissertations, and Problem Reports. 6191.

https://researchrepository.wvu.edu/etd/6191

This Thesis is protected by copyright and/or related rights. It has been brought to you by the The Research Repository @ WVU with permission from the rights-holder(s). You are free to use this Thesis in any way that is permitted by the copyright and related rights legislation that applies to your use. For other uses you must obtain permission from the rights-holder(s) directly, unless additional rights are indicated by a Creative Commons license in the record and/ or on the work itself. This Thesis has been accepted for inclusion in WVU Graduate Theses, Dissertations, and Problem Reports collection by an authorized administrator of The Research Repository @ WVU. For more information, please contact researchrepository@mail.wvu.edu. 


\title{
Marriage and Textiles in the American Civil War South \\ Hannah McClearnen
}

\author{
Thesis submitted \\ to the Eberly College of Arts and Sciences \\ at West Virginia University \\ in partial fulfillment of the requirements for the degree of \\ Master of Arts in History \\ Jason Phillips, Ph.D., Chair \\ Brian Luskey, Ph.D. \\ Melissa Bingmann, Ph.D. \\ Department of History
}

Morgantown, West Virginia 2017

Keywords: Textiles, American Civil War, Confederate Battle flag.

Copyright 2017 Hannah McClearnen 


\section{ABSTRACT \\ Marriage and Textiles in the American Civil War South}

\section{Hannah McClearnen}

This thesis explores marriage in the American South through textiles during the Civil War. Chapter One investigates the use of textiles by women to express political support and affection for their loved ones at the start of the war. Chapter Two examines the textiles couples circulated during the war and emphasizes that through the exchange of items, couples maintained an emotional connection. Chapter Three analyzes the textiles utilized for mourning and the lack of textiles that occurred in the South as production materials became more difficult to procure. Civil War couples utilized textiles to continue their marriages when separated. This thesis also focuses on the textile labor women performed in the home. This thesis attempts to illustrate the meaning that can be taken from material objects when studying the Civil War and their use in larger narratives. This thesis also evaluates how white women's labor in the home was valued during the Civil War: their labor was both an important patriotic effort but also a "labor of love." 


\section{Acknowledgements}

I would like to thank my thesis committee for all of their encouragement. Their comments were instrumental in completing this thesis. The staff of the American Civil War Center and the Virginia Historical Society were extremely helpful in finding sources. Finally, thank you to my parents, Nancy and Allen McClearnen, and Justin Deraway for their neverending enthusiasm and support. 
Table of Contents

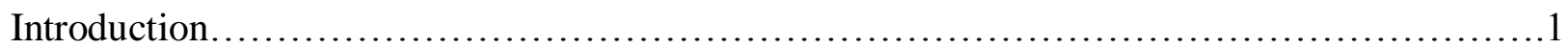

Chapter 1: Constructing Southern Marriages, Homespun, and Silk Battle Flags...............10

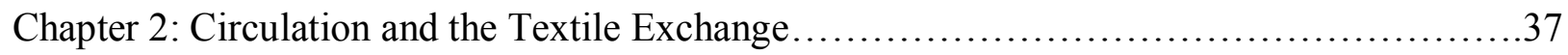

Chapter 3: Deconstruction, Mourning, Scarcity and Divorce..............................63

Conclusion..................................................................99

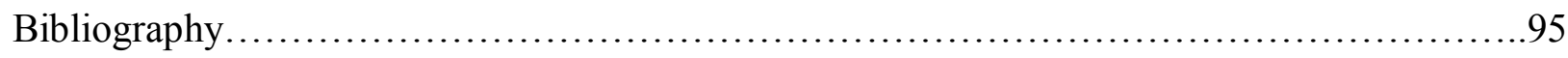




\section{Introduction: A Culture of Stitching}

Learning to stitch was an important rite of passage for women in the Civil War South: learning new skills and methods of fancywork strengthened the ideals of femininity. Women often learned to sew at home, likely taught by their mother, a female relative, or even a servant. Some women paid for lessons. Rachel Semon taught a fancy work class in her father's home. Women could learn to knit, sew, and embroider for six dollars per quarter from three to five thirty Monday, Wednesday and Thursday. ${ }^{1}$ In a section titled "New Publications" in October 1854, The Daily Dispatch advertised The Ladies Complete Guide to Crochet, Fancy Knitting, and Needle Work by Ann S. Staples. The guide contained a complete dictionary as well as clear instructions to make learning new skills easier. ${ }^{2}$ This guide illustrates the importance of stitching in American life, as well as learning how to stitch. The introduction of the guide claimed "that any person who can read, can in a few hours learn to execute the most complicated and difficult patterns in crochet and knitting." 3

Knitting, and other types of stitching, became representative of Confederate political ideals and relationships. Guides were a popular way for women to learn about needlework and expand their repertoire. This book, in the first chapter, argued that needlework "became a sort of medium by which women attempted to express their ideas and embody those affectionate thoughts that must have some expression to keep the full heart from overflowing." During the war, stitching was truly used to "embody" the ideals of Confederate women supporting the cause. By saying female hearts might have overflown without needlework, Stephens emphasizes

\footnotetext{
1“A Card to the Ladies" The [Richmond] Daily Dispatch, May 5, 1853.

2 "New Publications," The [Richmond] Daily Dispatch, October 25, 1854.

${ }^{3}$ Ann S Stephens, The Ladies Complete Guide to Crochet, Fancy Knitting, and Needle Work, (New York: Dick\& Fitzgerald, 1854).
} 
needlework was a medium for expression, whether politically or emotionally.

Confederate politicians, newspapers, and soldiers expected women to knit for the cause, and they were praised for their contribution. By sewing battle flags and uniforms for soldiers, women expressed their political beliefs in a forum that was deemed appropriate for women.

When the Civil War began, the stitching culture that pervaded antebellum America persisted and became linked to patriotism. Caring for the textile needs of a household became more vital for the household and their absent spouses on the battlefield. While Stephens claimed American women spent little time on needlework compared to other nations, American needlework was still a preeminent piece of lady's education and a popular hobby for women. Much of the antebellum population did not view needlework as especially expressive of women's thoughts, however, the guide writes, "let gentlemen deride these pretty occupations if they please; we know how much of a soothing influence lies in the dreamy habit of counting stitches, and how many bright faculties are pleasantly exercised in arranging and matching colors." Knitting provoked feelings of gentility and hospitality, and the downcast eyes made needle work the perfect feminine occupation to attract suitors. However, the author asserts that the gifts women produced were important, even for the Victorian people who denied needlework was a medium of communication.

The Civil War deeply affected many couples, but textiles, along with letters, were used to express affection when separated. Henry Bond wrote his wife Lizzie on May 1, 1861, "I want to get at it and fight it out and get back home and see my sweet wife and children and be there to stay and live in peace and not be always pestered to death about war." 5 When he wrote this sentiment, he expected a quick end to the war. He hoped he would be able to resume his married

\footnotetext{
${ }^{4}$ Stephens, II.

${ }^{5}$ Henry Bond to Elizabeth Bond, May 15, 1861, Bond Family Correspondence, Virginia Historical Society.
} 
life as it was before the war. While that may have been possible if he had been able to "get at it and fight it out," the following years of the conflict meant a prolonged separation that changed the lives of the couple drastically. During this time Lizzie had to make decisions about rearing their children and managing her home on her own. Henry Bond experienced the terror of battle and often wrote of his love and his desire to be home.

Married soldiers exchanged countless letters with their wives discussing domestic trials and their affection. Men and women also shared affection by exchanging textiles. In an 1861 letter, Bond answered his wife's inquiry regarding whether or not he needed a new pair of pants, he declined because he hoped to be home with his "sweet Lizzie" by Christmas time. ${ }^{6}$ Before that however, on September 16, 1861 he wrote to his wife asking for a knit token of affection, "you must knit me the Stockings. I should be so proud of them."7 In this statement, Bond characterizes the importance of the textile exchange, a set of stockings knit by his wife would not only serve as a reminder of home, but also keep his feet warm, and give him an opportunity to be proud of his wife's domestic achievement even when far from home.

Southerners conflicted over how to define the labor of white women. Elizabeth Fox Genovese argues the South was unique in that the home was still a center of production in Antebellum America. Southern women forged their identities based on their relationships with other women, men, and enslaved people. The paternalistic economy that existed in the South focused on the home as a center for production, and women oversaw much of this production. Work was valued based on who performed it. Work done by women was valued less then work done by men, and textile labor done by enslaved women was valued less than that done by

\footnotetext{
${ }^{6}$ Henry Bond to Elizabeth Bond, No Date, Bond Family Correspondence, Virginia Historical Society.

${ }^{7}$ Henry Bond to Elizabeth Bond, Sept 16, 1861, Bond Family Correspondence, Virginia Historical Society,
} 
plantation mistresses. ${ }^{8}$ Jeanne Boysdston argues that women's labor was devalued in the antebellum North. She finds that in the industrialized capitalist society of the North only wage earners were valued, meaning housework, lost its value. Boysdston emphasizes that women did not leisure in the home, they were kept busy with housework, and argues that women's labor was necessary to sustain the capitalist system. ${ }^{9}$ Within the Wartime South, newspapers often struggled with how to define the work done by women for the war effort. Work was referred to as a "labor of love," occasionally, and on other papers the work women did was seen as having value. $^{10}$

The Bond family was not unique in the Civil War: even while their husbands were far away, it was the duty of wives to supply the textile needs of their husbands. While historians typically focus on studies of the letters exchanged between couples, the textiles they exchanged are also illuminating. Textiles represented the inner workings of Southern marriages. Even if the couples were separated, the textile exchange allowed them to continue their relationship. Women supposedly supplied the textile needs of men better than anyone else, even the government that was charged with clothing their husbands. Michael Zakim argues that clothing served as a serious influencer in American culture in the Early Republic. In his discussion of the garment industry, he emphasizes that the clothing men wore held grand importance for their social standing. Zakim utilizes fashion as a "paradigm of liberal governance." 11 Joan Cashin argues that textiles were representative of major events in antebellum life whether it be a wedding dress

\footnotetext{
${ }^{8}$ Elizabeth Fox-Genovese, Within the Plantation Household, (Chapel Hill: University of North Carolina Press, 1988).

${ }^{9}$ Jeanne Boydston, Home and Work: Housework, Wages, and the Ideology of Labor in the Early Republic, (New York: Oxford University Press, 1994.)

${ }^{10}$ See: Staunton Spectator, March 1, 1864 and The Abingdon Virginian, October 31, 1862.

${ }^{11}$ Michael Zakim, Ready-Made Democracy: A History of Men's Dress in the American Republic, 1760 1860 (Chicago: University of Chicago Press, 2003): 3.
} 
or mourning clothing. ${ }^{12}$ Textiles marked rites of passage in the war, from the beginning when men joined the army wearing homespun, to the end when wives used mourning clothing to grieve. Therefore, textiles may be used to represent larger events in a civilian or soldier life. Textiles allow historians to study the inner workings of Civil War marriages. While Karen Lystra emphasizes that Victorian love was private, Nancy Cott argues that marriage was a public institution. A battle flag made of wedding clothing was a way textiles indicated that some aspects of marriage were often public, like political affiliation. Women who contributed their bridal clothes for a battle flag allowed the world to look into her marriage and view her support for the conflict and her husband. Nancy Cott argues that marriage in American history played a role in shaping political culture. During the Civil War, Cott studies marriage during a clash of laws that made divorce easier, free love, and a push back against the sanctity of marriage. Cott argues that marriage was used to shape the gender order. ${ }^{13}$

A battle flag made from silk wedding clothing was a strong illustration of support for the Confederacy. Wedding clothing was likely one of the most important textile items a woman would use in her lifetime. Deconstructing that garment to create a symbolic political item indicates women felt very dedicated to the Confederate cause because they felt devotion to the cause was worse the loss of a precious heirloom. However, sending a stocking to a loved one far from home with a letter was a more private declaration of love. Karen Lystra argues that romantic love within Victorian America followed ritualistic patterns. Lystra argues Victorians were experiencing companionate marriages that defined gender roles within relationships. ${ }^{14}$

\footnotetext{
${ }^{12}$ Joan Cashin, "Torn Bonnets and Stolen Silks: Fashion, Gender, Race, and Danger in the Wartime South," Civil War History 61, no. 4 (December, 2014): 345-6.

${ }^{13}$ Nancy F Cott, Public Vows: A History of Marriage and the Nation, (Cambridge: Harvard University Press, 2000): 3.

${ }^{14}$ Karen Lystra, Searching the Heart: Women, Men, and Romantic Love in Nineteenth-Century America, (New York: Oxford University Press, 1992).
} 
While Lysta uses letter collections as evidence, textiles might also be used to illustrate the affection that existed between wartime couples. Stephanie McCurry argues that poor white women, most especially soldiers' wives, had a great impact in politics during the war, and claimed power for themselves. In her discussion of poor white women, McCurry argues as women were no longer protected with marriage, their political acts became their own rather than their husbands. The symbolism of being soldiers' wives was an important political tool illustrating the ideal of marriage in the Confederacy was strong. However, poor women were not being provided for by their husbands. The ideal of marriage as an all-encompassing institution for women was losing power. ${ }^{15}$

While couples participated in the textile exchange throughout the Confederacy, the state of Virginia is the subject of this study. The proximity to the conflict and the army allowed couples to exchange large amounts of goods and letters through acquaintances travelling from the army to the home front. However, couples throughout the Confederacy will be included in order to create a narrative of marriage in the conflict throughout the South. While this argument will largely reflect Virginia, its implications relate to marriages throughout the South, as the phenomena of separation and changing roles were not unique to any Confederate state. Men and women depended on each other for fiscal and domestic support.

In many ways, the Civil War was enacted through textiles. People used textiles to indicate support for the war, to materialize affection for separated loved ones during the war, and finally, scarcity of textiles and mourning textiles indicated what had been lost in the Civil War South. This thesis will analyze what textiles represented in the Civil War, particularly within relationships between Virginian couples. Civil War men and women used textiles to support their

\footnotetext{
${ }^{15}$ Stephanie McCurry, Confederate Reckoning: Power and Politics in the Civil War South, (Cambridge: Harvard University Press, 2010): 120.
} 
loved ones, and textiles became representative of the relationship between man and wife during the Civil War. The textile exchange between wives and soldiers indicate its intertwined nature. The significance of this work is that it attempts to illustrate the meaning that can be taken from material objects when studying the Civil War. Its source base comes from letter collections within the Virginia Historical Society as well as Virginian newspapers. This study has been divided into three chapters, each of which analyzes different textiles that were symbolically important during the war, and different aspects of wartime relationships.

The first chapter analyzes silk battle flags made from the dresses of Southern ladies, as well as the Southern homespun fabric produced in the beginning of the war. By giving up their wedding dress, the most significant clothing a woman would wear during her life, women showed their support for the Confederate cause, but also for their husbands. In turn, the silk battle flags reminded men of the women who stitched the flags. In The Confederate Battle flag John Coski studies how the Confederate Flag became the symbol of the Confederate nation. $\mathrm{He}$ analyzes the flags meaning for those who support and those who condemn the flag. This work allows the opportunity to illustrate the meaning of battle flags, such as the silk flags women made from their bridal clothing. ${ }^{16}$ The flags took on meaning for both women at home and men on the front. Homespun fabric also served as representative textile items. Forgoing the expensive clothing produced elsewhere at the start of the war showed support for the Confederacy, and women were largely tasked with producing and wearing the fabric that was supposed to be superior and Southern.

The second chapter analyzes the textile exchange. Wives and husbands exchanged textiles during the war. Women sent stockings and uniforms, and fabric might be procured by the

\footnotetext{
${ }^{16}$ John M. Coski, The Confederate Battle Flag: America's Most Embattled Emblem, (Cambridge, MA: Belknap Press of Harvard University Press, 2005): 7.
} 
husband and sent home during the war. This chapter allows a glimpse into the practical and emotional aspects of war time separation. When women knit stockings for their husbands and sent them with love letters, they reminded their husbands of their affection. When men like Bond replied by stating the pride they felt in their wives needlework, it indicates they recognized the knit contribution as significant, illustrating that an emotional connection was kept through the textile exchange.

Finally, the third chapter discusses wartime scarcity as well as mourning clothing. The death toll in the war devastated many marriages. Both men and women mourned their loved ones during the war, and textiles were an essential part of the mourning process. Scarcity also affected the textile exchange and made it more difficult to procure any fabric items. How the dead were mourned was seen as significant. Women who could not properly mourn their husbands were pitied, and other women took their mourning practices seriously. Drew Gilpin Faust argues that was work for Civil War Americans. She characterizes what soldiers and civilians alike believed was a good death, and illustrates the difficulty soldiers faced when they were far from home. Soldiers had to come to terms with death, which was difficult when so many of their comrades died horrifically and far from home. Faust emphasizes how women were largely expected to do the work of mourning. ${ }^{17}$ The textiles used to mourn their loved ones honored their memories and their loss, indicating the representative embodiment of mourning textiles. When they became scarce, many struggled to reconcile events that could not be marked with textiles.

Textiles have the opportunity to frame public history. In Presence of the Past, David Thelen and Roy Rosenzweig conducted a survey of Americans and their interest in the past. While this study has grown old, its implications remain relevant. At the time of the survey, the

\footnotetext{
${ }^{17}$ Drew Gilpin Faust, This Republic of Suffering: Death and the American Civil War, (New York: Alfred A. Knopf, 2008).
} 
respondents stated a high regard for objects for historical information because museums represent truth. Museums held objects, which were supposedly the most honest form of studying the past. ${ }^{18}$ People today continue to associate objects with the truth of the past. With objects, like the battle flags, stockings, and mourning clothing in this study, broader interpretations might be used for object based teaching.

Women experienced the war through textiles. In the beginning, they stitched battle flags and homespun their loved ones could wear into battle, and to indicate their pride in the sunny South. As the war continued, Soldiers increasingly dealt with scarcity and erosion of clothing. When winter came, cries of bare feet prompted women to send their husbands and loved one stockings, as well as uniforms. On the home front, women began to struggle to collect the items they needed to support themselves and their children. Husbands attempted to send necessities as well as fine items home to their wives. However, the textile exchange was forced to slow because of war time scarcity, and for many couples it ended completely due to the death the war wrought. The rhetoric surrounding homespun fabrics and silk battle flags illustrate the political feelings of women supporting both their husbands, and the Confederate cause.

\footnotetext{
${ }^{18}$ Roy Rosenzweig and David P. Thelen, The Presence of the Past: Popular Uses of History in American Life, (New York: Columbia University Press, 1998).
} 


\section{Chapter 1: Constructing Southern Marriages, Homespun, and Silk Battle Flags}

At the outbreak of the Civil War, the citizens of the Confederacy were looking for a way to contribute. Men enlisted, but their wives were unable to join the fight. During the war the basic relationship between husband and wife was manipulated in order to encourage enlistment. Marriage was first and foremost an institution of the state. Wives were pressured to ensure that their husbands enlisted, but many wanted to do more — not only to support their country, but also to support their husbands. For many couples, the war represented the first long-term separation their marriage had to endure. Wives did not want to send their husbands away without a tangible way for them to remember their love, often in the form of silk battle flags made from their bridal clothes. However, married women were not the only ones who participated in this phenomenon: unmarried women wore homespun, not only to support the South and soldiers, but also to exemplify ideals of womanhood so that they might marry a soldier during or after the war.

Women volunteered textiles in a way that was not only symbolic of their love and devotion for their husbands, but a political statement of support for the cause their husbands fought for. By constructing the Southern Confederacy, the Union was deconstructed. By constructing new battle flags and fabrics, women deconstructed other fabrics. These flags served as reminders of love and spousal devotion for those fighting the war, but also the political and social marital consequences of fighting the Civil War. The homespun fabrics and the silk battle flags women embraced exemplified not only their commitment to their husbands, loved ones, and potential future spouses, but also their political support for the Confederacy.

Mary Dickison, when sending her husband J.J. Dickison off to war, wanted to send him with a memento of their love, but also a reminder of why he was fighting the war. To do this, Mary Dickison used her bridal clothing to stitch together a flag. The flag she created with her 
friends in Marion County, Florida was made to represent their pride in their new country and the relationship between the women who created the flag and the men who fought in the war. The addition of bridal clothing and the comb from her wedding night emphasizes that this flag represented the household, not only for her husband but for all of the soldiers fighting under it. Her husband, J.J. Dickison, was extremely well known in Florida, and in order to preserve his legacy, Mary Dickison wrote a book that detailed his war time experience. ${ }^{19}$

Within Dickisons' book, the flag was treated as representative of the women who stitched the flag, illustrating the flag held emotional significance for many of the soldiers who fought under the flag. Dickisons' book was written while her husband was still living, likely with a large amount of his input. This was a communal effort between husband and wife to ensure he had a longstanding military legacy. Therefore it is particularly meaningful an entire chapter of this work is dedicated to the flag that Dickison made from her bridal clothing: both husband and wife saw the flag worthy of a chapter. The chapter about the flag represents how textiles were embodied during the Civil War for Southern citizens. The fact a scrap of fabric merited a chapter in the story of a Southern hero, illustrates the nature of Confederate material culture. The flag was not simply a scrap of fabric, but it represented the presence of the women of Marion county, and the Southern cause, and that merited honoring. Mary Dickison wrote, "Though only a silken banner, there was a silent eloquence around its crimson folds that made it seem to them a "thing of life." Dickison herself called the flag more than material, it was a living object with the ability to alter the course of the war. Dickison continued to write, "Every heart that has "bled like thine and mine" can enfold you in a sympathetic embrace." This section emphasizes that the flag,

\footnotetext{
${ }^{19}$ Both the editor and the introduction claim that this book was likely at least dictated to Mary by her husband as opposed to begin solely her own work. The complimentary nature of the work would have been more acceptable if written by his wife However, this book being a joint venture between husband and wife indicates the strength and united purpose of a strong post war marriage.
} 
billowing in the wind represented the love of the women at home for those who fought the war. "That flag told you the sad, sad story, that so many hopeless, anguished hearts had learned, of the young and brave hearted, who had buckled on their armour and gone forth from peaceful, happy homes with a mother's, wife's and sister's kiss warm upon their dear lips," this section once again emphasizes that the flag was meant to remind the soldiers of the women, not only because they stitched the flag but it represented physical aspects of loved ones, like a warm kiss. Their cause, Dickison argued, was to be "strong in the resolve to drive back the ruthless invaders who had desolated our fair prosperous land, who had marched even to...the sanctuary of our homes and desecrated that God-given refuge to weary man." ${ }^{20}$ According to Dickison, the flag represented the Southern homes that the Confederate army was protecting. The flag represented how the women of Marion Country supported their husbands and suitors fighting the war effort, and because of this the fight was worth continuing.

The textiles people held onto during their lives were just as meaningful as letters they saved. Leora Auslander has written historians are far too reluctant to use material sources to answer old questions. Auslander refers to objects as "embodied," because they occupy space, and like people, objects have a lifespan. Clothing specifically has great effect, even beyond changes in styles because historical actors expressed their emotions through textiles. The things people owned reflected who they believed they were, and who they wished to be. Auslander specifically mentions how space and material might be used in histories of domesticity. ${ }^{21}$ This is true, because domesticity occupied a specific space, the home, and the different spaces of the home had different meanings. In the Civil War, the entire space of the home was hyper-feminized because of the absence of males. Joan Cashin has also shown that textiles had large amounts of

\footnotetext{
${ }^{20}$ Mary Dickison, Dickison and His Men, (San Marco Bookstore, 1984): 23.

${ }^{21}$ Leora Auslander, "Beyond Words," The American Historical Review 110, no. 4 (2005): 6-9, 20, 60.
} 
ritualistic meaning for Americans during the Civil War. Auslander defined textiles as important in part because of their ceremonial meaning, and Cashin agrees with her discussion of the various rituals in which textiles played a role. Textiles played a central role at weddings, at births, and in mourning. For these events, female family members often banded together in order to sew all necessary items. The creation of clothing, was considered a sign of femininity. ${ }^{22}$

Sewing a silk battle flag was one way women supported their community and also tailored a narrative in which their husbands were fighting for protection of the home front. As secessionist tensions rose in the summer of 1861 , militias formed, and women began making silk battle flags for the units. Mary Dickison boasted in her book about having the first rebel flag with a palmetto tree, "Proudly its azure folds waved over my peaceful home, its comforting and soulcheering watchword, "In God We Trust," smiling upon a happy wife and mother. Alas! The sad changes that followed, these reminiscences only very faintly reveal." ${ }^{23}$ While John Coski argues most battle flags made from bridal clothing were not taken into battle, battle flags were a source of "pride and morale." 24 Not only did they have grand representational meaning for the soldiers in battle, but they were also meaningful for those who made the flags. The flag indicated a wife was clearly proud of her home, as well as the flag that followed her husband into the war. A silk flag was often presented with a flag presentation ceremony. While many silk flags were sent home early in the war, others followed soldiers as they fought in early key battles. Wayne Durrill argues that the flag represented loyalty, and were therefore "treasured because each hole or tear

\footnotetext{
${ }^{22}$ Joan Cashin, "Torn Bonnets and Stolen Silks: Fashion, Gender, Race, and Danger in the Wartime South," Civil War History 61, no. 4 (December, 2014): 345-6.

${ }^{23}$ Dickison, 160.

${ }^{24}$ John M. Coski, The Confederate Battle Flag: America's Most Embattled Emblem, (Cambridge, MA: Belknap Press of Harvard University Press, 2005): 7.
} 
told a story of blood and bravery." 25 The silk flags symbolized to the soldiers fighting in the field that they were fighting for their wives and their future.

Textile items made by women for their husbands had political influences that were utilized by newspapers and authors to encourage support for the war effort. Durrill argues when the Confederacy began having trouble convincing its sons to join the Confederate army, flag ceremonies served as patriotic incentives. Flag presentation ceremonies were covered step by step in Southern newspapers, and then, years later, unit reunions where the flag was once again presented were also detailed piece by piece in papers, illustrating the long-term strength the flag had in Civil War memory. ${ }^{26}$ Dickison's book also illustrates the importance of the flag. In her book, she includes not one, but two poems about putting the Confederate flag away. ${ }^{27}$

Early flags, made before silk became scarce, were not made from lady's dresses, bridal or otherwise, but the imagery was powerful. Constance Cary Harrison, one woman who created a battle flag from silk, emphasized later she did not participate in the bridal clothing phenomenon, "It is generally stated by historians that these flags were constructed from our own dresses, but it is certain we possessed no wearing apparel in the flamboyant hues of poppy red and vivid dark blue required." 28 The Cary sisters were prominent figures in Southern society. They married prominent men, and were well known in Richmond, Virginia. The Cary sisters mocked the trend that so many other women wholeheartedly embraced by emphasizing the colors of battle flags were too "flamboyant" for regular wear, and thereby emphasized the importance of fashion to Southern women. Even though the women did not use their own clothing, people wanted to

\footnotetext{
${ }^{25}$ Wayne K. Durrill, "Ritual, Community and War: Local Flag Presentation Ceremonies and Disunity in the Early Confederacy" Journal of Social History 39, no. 4 (Summer, 2006): 1107.

${ }^{26}$ Durrill, 1106.

${ }^{27}$ Dickison, 150.

${ }^{28}$ Constance Cary Harrison, Refugitta Of Richmond : The Wartime Recollections, Grave And Gay, Of Constance Cary Harrison, (Knoxville, Tennessee: University Tennessee Press, 2011): 42.
} 
believe they did because of the strong imagery it represented. Those who wrote of the Cary sisters wanted the flag to have come from bridal clothing because it exponentially increased its meaning. Giving up clothing, something essential to the daily life of Confederate women, was viewed as a sacrifice to the cause. Battle flags symbolized Confederate nationalism, however, to soldiers fighting with a silk flag made by bridal clothes of the wife of one of their unit, the meaning increased exponentially from nationalism to marriage, and traditional Southern womanhood. ${ }^{29}$

Wives sacrificed their bridal clothing so their husbands could bring a treasured memory and their support into battle. This action was not only patriotic, but also a showing of grand spousal devotion. Silk was not a practical fabric to use for battle. It was far too luxurious, and standard issue flags were instead constructed with wool bunting. However, silk fabrics were attractive. If women wished to make a grand statement, using silk fit the purpose. While some battle flags made from bridal gowns were made out of necessity and the lack of availability, others were made because of a conscious choice of what that particular fabric represented. Cary described the flag she created with great pride in her memoir, a pride similar to that which she referred to her husband. She wrote, "My flag went with him through much brilliant service to the Confederacy in Virginia, in the trans-Mississippi, and the States of Tennessee and Mississippi. It was torn with bullets and stained with the smoke of Pea Ridge, Corinth, Iuka, Holly Springs, and other battlefields, when, after his death, it was finally put back into my hands. ${ }^{.30}$ Cary Harrison did carefully follow her flags journey. Charles Dillon, one of the men who fought under the flag,

\footnotetext{
${ }^{29}$ Coski, 9.

${ }^{30}$ Cary Harrison, 42.
} 
once visited Harrison to express his appreciation. According to her memoir, he told her, "You're the lady that made our head-quarters battle-flag, Miss, and we think a good bit of that flag."”31

The shift to a new flag was difficult for some Southerners, making the silk flags important as they represented feminine support of the war effort. Jefferson Davis, P.G.T. Beauregard, and other Confederate politicians and generals attempted to lead the nation to accept a new emblem, indicating the importance of a Southern banner that held the same emotional hold as the Stars and Stripes. The silk flags made by ladies inserted women into the debate. Flags represented feminine sacrifice. Many Southerners were still attached to the Union flag, and ideals of unionism, so it was difficult to let those ideals go. Robert Bonner likens flags to religion, as the "purity" of banners were important to Confederate citizens. Beauregard was especially active in attaching ideals of femininity to flags, and he often reminded the soldiers that the flag represented their wives and loved ones at home. ${ }^{32}$ Coski argues that sentimental value was eclipsed by confederate nationalism, even though the hold sentimental value had on soldiers was still very strong. For the Confederate nation, the flag was history as it was supposed to be, these flags represented the ideal that wives completely and totally supported the war effort. These silk flags made by ladies were so present in memory and popular culture, it is almost surprising to remember that the most common flags were issued by the army and made of wool. ${ }^{33}$

As the war continued and enlistment rates slowed, flag presentation ceremonies were used to encourage men to enlist by indicating enlistment might help a young man establish a household. This illustrates that political arguments were often not enough, and social rituals were

\footnotetext{
${ }^{31}$ Cary Harrison, 43.

${ }^{32}$ Robert E. Bonner, Colors and Blood: Flag Passions of the Confederate South, (Princeton.: Princeton University Press, 2002): 15, 18. 53, 81, 84.

${ }^{33}$ Coski, 11. 33. 40-41, 63.
} 
also needed to pressure men to enlist. These ceremonies were indicative of the gender roles that framed the actions of both husbands and wives. The ceremonies emphasized ideals of masculinity. However, access to young white women for new volunteers became a theme in the flag ceremonies. They came to emphasize young wives, and also possible brides. The war, and success in the war, represented the "chance of marrying these sexually desirable white woman...If a soldier wanted to marry a beautiful young virgin and establish a new household, he had no alternative but to join the confederate army." 34 Durrill successfully illustrates that the Civil War, through flag presentation ceremonies emphasizing battle flags made with silk, not only symbolism of current loves and marriages, but also the possibility of a future marriage. McPherson refers to the aura surrounding the flag as a sort of "mystique." Few jobs were more honorable than bearing the colors. ${ }^{35}$

While some women proudly sent their husbands to war with a battle flag, many others did not wish to send their husbands into war. While many silk flags were sent home early in the war, others followed soldiers as they fought in early key battles. Wayne Durrill argues that the flag represented loyalty, and were therefore "treasured because each hole or tear told a story of blood and bravery." ${ }^{36}$ The silk flags symbolized to the soldiers fighting in the field that they were fighting for their wives and their future. The textiles women made for their husband not only illustrated spousal devotion, but also a commitment to the cause, none more so than a Confederate battle flag that might convince others to enlist. Durrill argues that because of this, ministers often spoke using both romantic and religious images to encourage women to continue to tell their husbands and suitors to join the fight. Durrill argues "labor embodied in the design

\footnotetext{
${ }^{34}$ Durrill, 1112. Also see, 1108, 1111.

${ }^{35}$ McPherson, 84.

${ }^{36}$ Durrill, 1107.
} 
and fabrication of the flag itself...symbolized the social bonds soldiers would surely forfeit if they did not fight... Flag presentation ceremonies allowed no place for women who did not wish to send their...husbands into battle." ${ }^{37}$ However, women continued to support their husbands as they enlisted to fight in the conflict with textiles and love, even as economic hardship made life without a husband especially difficult. ${ }^{38}$ Women sacrificed their bridal clothing on top of other sacrifices they made for the war effort. Mary Dickison did not become a widow during the conflict, but her son did die while fighting under her husband. Regardless, she remained proud in her work. He died for what she saw as a noble cause and under a flag that she created herself. ${ }^{39}$ Other women who did lose their husband during the conflict remained proud that they lost their lives fighting under their flag. Battle flags often did not return to the woman who donated her bridal clothes, but to the widows who requested to own the flag their husbands fought and died under.

Soldiers who fought under a flag made of the bridal clothing of another man's wife were also affected by the experience, as the flag represented the household, whether the one they already had, or one they wished to create. One of the soldiers in the Florida Light Artillery Unit who fought under the flag Mary Dickison made for their unit was so moved by its presence he wrote a poem in honor of the flag. Written in the midst of the war, the poem described how the flag led the men to join the Confederate army, and then led them into many battles, waving proudly. The poem claimed "That Flag waved above us, in crimson and gold, And looked smilingly down, from each graceful fold," meaning that for the soldiers in the unit, the flag was ever present in their minds. The language used to describe the poem is representative of

\footnotetext{
${ }^{37}$ Durrill, 1118.

${ }^{38}$ Durrill, 1117.

${ }^{39}$ Dickison, 77.
} 
femininity, as "graceful fold" seems to relate to maternal grace. While any flag made of silk might have graceful fold, the language ascribed to this flag is especially significant because of the emphasis on marital harmony in the poem. This indicates the flag represented domesticity and femininity to the soldiers fighting under it. "If a pulse beat faster, or quivered a nerve, A glance at that Flag forbade any to swerve." 40 This poem indicates some things about masculinity that are important not only for the entire unit, but especially for husbands. The poem allows that battle caused men to pause, and experience fear. However, the flag represented soldiers' wives, and therefore represented the household, which was supposed to prompt men forward and encourage them to defend their household.

Any Confederate flag might be seen to represent the household, as well as any number of things in the Southern Confederacy, however, flags made from bridal clothing were often viewed as especially significant because of the women who stitched them. As opposed to being manufactured at a faraway manufacture, it was created by someone the men were familiar with, and above the household, the flag would have been associated with marriage. The poem recognizes that their banner became "tattered and torn," which seems representative of not only the Southern Confederacy that they were fighting for, but their marriages as well. Even if separation and economic desperation caused struggles, their homes were still worth fighting for. Some members of the company were "slain in the fight, they saw that Flag safe, with their last look in life." ${ }^{41}$ The flag, the representation of marriage and household, was worth dying for. This illustrates how great a connection marriage and the household had in the military. Regardless of loss, "Our Flag cheerily waved, and looked smiling on." ${ }^{42}$ The flag acted as a source of morale

\footnotetext{
${ }^{40}$ Dickison, 20.

${ }^{41}$ Ibid., 22.

${ }^{42}$ Ibid., 21.
} 
on the battlefield, "Aloft waved our Flag, and almost seemed to say, We can even lose him, and can yet win the day." ${ }^{43}$

Colonel Stockton might have taken particular meaning in the flag because he was one of the men who was forced to leave a wife behind in order to fight in the war. Due to the respect and friendship held between Mary Dickison and his wife, it is likely Julia participated in stitching this flag. Dickison later referred to Julia as the "noblest and bravest of her sex," due to how she raised her children after Colonel Stockton's death with "more than a man's courage." 44 Based on inference that can be made from the poem as well as Dickison's writings, the Stockton's had a strong wartime marriage. It may have imparted great meaning that the women of Marion County, Florida, likely including his wife, created the flag that waved above Stockton as he fought to keep the people of Florida safe—the particular job of Dickison's men.

The idea of the flag was tied closely to bravery, but also the affection of loved ones at home. In an article in which the poem was included from the Columbian, the author wrote, "The name of 'Dickison' on the banks of the St. John's is a host of itself, such is the confidence reposed in him and his command, that there is felt a perfect security from the advance of the enemy." ${ }^{45}$ The rest of the poem goes on to describe the importance of the flags' origins to the men fighting under it, "That flag has a story which now shall be told! The women of 'Marion,' the loved ones we have left To furnish that Banner, themselves had bereft Of mantle and brooch, of rich comb and of ring, With soft uttered prayers which to heaven took wing." In the first stanza, Colonel Stockton admits that the flag itself has a story in the midst of the war. It began with the women of Marion stitching the flag. Colonel Stockton mentions the comb used to attach

\footnotetext{
${ }^{43}$ Ibid., 21.

${ }^{44}$ Dickison, 40-41.

${ }^{45}$ Dickison, 71-74.
} 
the flag to its staff was made of a comb, which was significant because Mary Dickison wore it on the evening of her wedding, presumably the night she lost her virginity. That comb embodies the virginity of Southern women, reminding the soldiers of the innocence they were supposedly fighting for. The poem continues by describing the flag, "Those soft folds of rich crimson, from far distant land-Had screened beauty's form, from the rough blowing wind. Those brooches from fair bosoms, so earnestly given, Which devotion to country alone, thence had given; Those rings from fair hands, so soft and so light." The description of the flag was accompanied by a description of the fair hands that created the flag. This once again emphasizes the flag was a materialization of the loved ones waiting for soldiers at home.

The flag reminded soldiers of loved ones at home, but was also described in terms of success, life, and death. It took on its own identity during the war. "God and our Rights"— twas the brave Norman old war-cry, Which the Puritan strikes at, but for which we will die." The flag represented life and death to the soldiers fighting under it. "Our soil have the Red Bay, fit emblems of pride, For the staff whence the sheen of our Banner gleams wife. The comb, which had a fair bride's tresses restrained, To guard e'en its base, in its bright silver designed. Then thanks to the loved ones who pray for us now, They never need fear, lest we fall in our vow."46 The flag represented success to the soldiers. They could not fail because they needed to keep their loved ones safe, but also because they could not lose that flag. If the enemy was able to capture the flag, the enemy would have been successful in figuratively capturing the virginity of Southern women. If the soldiers who fought under the flag found so much meaning in its origin, then the effect must have been greater for the husband on the battlefield who gazed at the flag made from the bridal clothing of his own wife.

\footnotetext{
${ }^{46}$ Colonel William T. Stockton. "The Flag of the Florida Battery: The Marion Light Artillery in the Battle of Richmond Kentucky" Museum of the Confederacy. (Also included in Dickison, 20-22.)
} 
While companionate marriages were prominent in the nineteenth century, marriage remained a political institution. According to Nancy Cott, marriage was a product of the state, and therefore an extremely public institution. Cott argues "molding individuals selfunderstanding, opportunities, and constraints, marriage uniquely and powerfully influences the way differences between the sexes are conveyed and symbolized....it is the vehicle through which the apparatus of state can shape the gender order." ${ }^{47}$ Though marriages might be formed for private love, their purpose was utilitarian: the wife gave her rights of citizenship and representation to her husband in return for her guaranteed protection. By controlling marriage, the state controlled the sexes and gender roles. Also in return for her guaranteed protection, the wife was "obligated to give all her service and labor to her husband." 48 This arrangement was the basis to marriage as much as, if not more so, than love.

Many aspects of marriage were public because marriage was regulated by all aspects of society. Cott argues that most people did not understand to what extent their marriages were managed at the federal, state and local levels, but the local community was by far the best regulator for marital behavior. Local communities took great interest in individual marriages, and those within a marriage acted as the community believed they should to avoid censure. Monogamous love was important, not only to the individuals in the couple but also the rest of the community. Marriage was so promoted by the state within the United States that it was far easier to marry in America than other countries, as long term cohabitations with questionable ceremonies might be labeled as marriage. Cott specifically references the schism in the Civil War, the South would have been far different from the North, but marriage would have still been

\footnotetext{
${ }^{47}$ Nancy F Cott, Public Vows: A History of Marriage and the Nation, (Cambridge, Mass: Harvard University Press, 2000): 3.

${ }^{48}$ Cott, 12 .
} 
regulated within communities. Marriage in the South was regulated differently. It was assumed black men were especially interested in white women, and women, being frivolous, needed to be protected within the institution of marriage. ${ }^{49}$

Textiles represented both the companionate and the political sides of marriage. While Karen Lystra saw evidence of a deep and private love in courtship, and a more practical relationship indicated through married letters, the Civil War correspondence of many paints a different picture. Love, and intimate details of relationships were ever present in correspondence. ${ }^{50}$ When Nancy Cott argues that within the public institution of marriage a wife was responsible for laboring for her husband, that ideal is clearly evoked by the textile production in the Civil War South. Women worked hard to outfit their husbands with the best materials they acquired, although that often meant sending them slightly malformed socks. Even when husbands were away, and when they were supposed to be taken care of by their government, women continued to labor for their husbands. Through this argument, marriage takes on new meaning. This exchange of textiles represented a materialization of affection, but also represented the very public aspects of marriage. Marriage was a public institution; therefore, a wife's labor was public as well. Textile gifts were materializations of support for their spouse, and through that, support for the Southern Confederacy as well, begrudging thought it might be. Marriage was the best way to organize the state, and therefore guarantee support for the Confederacy's war effort. When flags made from the bridal clothing of Southern women were presented in lavish flag presentation ceremonies, they represented marriage in a way that was beneficial to the state. Through the textiles women made for their husbands, whether the battle

\footnotetext{
${ }^{49}$ Cott, 22-24, 36-39, 42, 49-50.

${ }^{50}$ Karen Lystra, Searching the Heart: Women, Men, and Romantic Love in Nineteenth-Century America, (New York: Oxford University Press, 1992).
} 
flags from their bridal clothing or simply homespun dresses, women illustrated their support for their husbands as well as the state. As Cott argues for the importance of all levels of government for the regulation of marriage, being a patriotic couple was important for local approval and regulation.

Women throughout the South expressed pride in homespun goods they created, but often desired purchased fabrics. Elite women throughout the South struggled to find the materials they required to create the textiles they needed. It was a disappointment to many that they were forced to work so hard for textiles that were below the standards to which they were accustomed. Women like Mary Watkins, however, were still proud of the garments they had created, "I believe us Southern people can make everything at home now, unless it is cotton cards. . . Mama sent her samples of all of our homespun dresses....We could make our own hats, bonnets, dresses, shoes, bed cords, fans and everything else we needed." ${ }^{51}$ She followed this mandate by claiming that partly due to this textile self-sufficiency, the South no longer needed the North. Mary was clearly very proud of the goods Southern women like her had created. Despite their apparent pride in homespun fabrics, Mary Watkins and other Southern women were clearly desperate for nicer and more luxurious fabrics, as exhibited by how excited Watkins was about two beautiful calico dresses her husband had sent her. ${ }^{52}$ While calico might not generally be considered a luxurious fabric, during the war it was certainly a sign of luxury to have a special dress made by fabric the plantation household did not need to spin and weave itself, or even to construct the garment at all.

During the Civil War, the ideal of homespun became extremely powerful. Women were encouraged by newspapers, and politicians like Jefferson Davis, to accept homespun as

\footnotetext{
${ }^{51}$ Watkins, July 27, 1863, 208.

${ }^{52}$ Watkins, July 27, 1863, 208.
} 
fashionable and produce homespun materials. Even following the war, the Staunton Spectator reminded Southerners of the beauty of a proper Southern woman robed in homespun, "The good girl by the spring, robed in homespun cotton, with the light of loveliness around her, is a queen with a right divine from heaven.. ${ }^{, 53}$ In the nineteenth century, homespun was representative of femininity and simplicity. In Twenty Years Ago, Josh Jones wrote a nostalgic song in 1860 about life twenty years before. He wrote, "The girls took music lessons, Jim, Upon the spinning wheel' and Practiced late and Early Jim, Upon the spinning wheel....In cloth our gals had wove." ${ }^{54}$ This song presents a nostalgic narrative for a cottage industry, a time where women spun and wove cloth for their families.

While Twenty Years Ago was not an accurate representation of 1840, it represents how people in the South, like in New England, held sentimental views of homespun, and the act of creating homespun. Laurel Thatcher Ulrich argues that in New England, homespun items were representative of the changes in New England society, and were often equated with older and more simple times. As Ulrich argues, nineteenth-century families felt objects were important enough to carefully save, and Southerners also preserved the items they created, whether a battle flag, or a stocking. For New England, Ulrich cites the importance of the image of revolutionary women creating homespun for the conflict, and this being a proud narrative. Mention of Virginian Revolutionary War women was also prominent in Virginian newspapers. Ulrich also touches upon how in the past, a woman spinning wool alluded to her sexuality and was supposed to be both attractive and productive, two pieces of an ideal wife. ${ }^{55}$

\footnotetext{
${ }^{53}$ Staunton Spectator, May 1, 1866.

54 Josh Jones, “Twenty Years Ago," Staunton Spectator, August 7, 1860.

${ }^{55}$ Laurel Thatcher Ulrich, The Age of Homespun: Objects and Stories in the Creation of an American Myth, (New York: Knopf, 2001): 14, 35.
} 
Southern homespun was often praised, but its allure was dimmed by the labor necessary to produce patriotic fabric. While Ulrich creates a narrative for New England, the legend surrounding homespun was alive in the South as well, albeit in a different manner. Ulrich describes the feminization of weaving, and also how unnoticed labor, like that represented by a niddy-noddy, was so essential. Ulrich argued, "Turning to their wheels, young women won the hearts of young gentlemen and the gratitude of their country." Ulrich clearly defines New England as a society in which attraction and courtship manifested itself through homespun. Southern homespun was different, such industry was not seen as so simply honorable as it was in New England. For as much as newspapers praised homespun and the elite women who turned to create it, Southern society continued to war with its desire for fashion and its desire for a patriotic and Southern fabric. Ulrich portrays one New England woman as a "hostage" to her textile production, as it was more present in her diary than any other life details. Ulrich describes how as hand-spinning declined in New England knitting replaced in the eyes of femininity. In her afterword, Ulrich emphasizes that the age of homespun was an urban myth for rural America to hide that America's past was violent and economic, as the history of textiles is economical. ${ }^{56}$ This is also true for the South. The idea that the homespun age "twenty years ago" held any superiority was false. However, for this narrative, textiles were also representative of a narrative of love. When Confederate soldiers looked at homespun, they did not simply see a handmade fabric, they viewed Southern industry and Southern femininity. Material things were visions of the entire Southern cause.

The South was known internationally for its cotton production, however, they relied on non-Southern industry to utilize the cotton for textile production. Sven Beckert, commented on

\footnotetext{
${ }^{56}$ Ulrich, 211, 376.
} 
the fact that in order for an Empire of cotton to be created, the homespun lifestyle in which women spun and wove their own cloth had to disappear to make space for the large industrial factories, largely in England, to make cloth. Beckert refers to the economic market as "war capitalism," because the European cotton empire was built through the laboring of the enslaved in harsh conditions. In this economic market, the American South produced cotton and England, using its great industry, spun and wove it into cloth. It is almost ironic that a place produced so much cotton did so little with the production of cotton, beyond that done by and for enslaved people until the Civil War. England relied on the Confederacy, because England had outlawed slavery, and the empire of cotton required enslaved labor. England also did not want the United States manufacturing its own cotton in centers of industry. The Civil War revolutionized the cotton market abroad. The South was producing an astounding amount of cotton in the Civil War, but it was not producing it into fabrics. ${ }^{57}$

The South was by no means a homespun community, but it did get the bulk of its fabrics from external sources, leading to the struggles for fabric they were forced to endure during the Civil War. This lack of production led newspapers to encourage Southern women to spin and weave, so that the South could continue to operate on its limited fabric supply. ${ }^{58}$ In fact, Virginia Clay Clopton, the wife of a Senator and a well-known political matron who published her memoir, wrote, "the industries of our country yielded but a common grade of materials designed for wearing apparel, and were altogether unequal to the demands of a capital in which the wealthy vied with their own class in foreign cities in the acquisition of all that goes to make up

\footnotetext{
${ }^{57}$ Sven Beckert, Empire of Cotton: A Global History, (Knopf: New York, 2014): xi, According to Beckert, English manufacturers were angered the government did not take action in this conflict. Slavery and the cotton industry went hand in hand, and the British government relied on the labor of slavery for cotton supply. However, during the global crises and the blockade, the British simply got their cotton from elsewhere.

${ }^{58}$ Ibid., 242-273.
} 
the moods and character of fashion." By this, she meant that the cotton the South produced was not suitable for the elite Southern women such as herself. Clothing, and fashion were too important to be left to any common denominator. She continued to say, "Our gloves and fans and handkerchiefs, our bonnets and the larger part of our dress accessories, as well as such beautiful gown patterns as were purchased ready to be made up by a New York or Washington dressmaker, were all imported directly from foreign houses." 59 This market she described created a great deal of commerce for the Confederacy, and was essential for an elite lifestyle.

Regardless of class most women were able to do some kind of stitching. A soldier leaving for war was considered another of the essential life events for which women were meant to stitch for. Through clothing, Southern women were able to show their support for the war. When soldiers sent home for specific items of clothing, or clothing made in a specific style. The specific fit was not only a question of style, but also an indicator on the importance of clothing to men as well as women. Cashin claims that "garments symbolized the plantation elite's power" and "soldiers might perceive clothes as implements of war." 60 Textiles were not merely items that clothed the Civil War populace: they nurtured their morale and hope for a successful end to the war, and they served as symbols of status and domesticity.

Textile items were extremely important to Southern women, and the larger South, as illustrated not only by how often women mentioned textiles in their diaries, but also how Southern men and women referenced textiles and gave them greater meaning. Clay Clopton recorded an instance where she felt fashion influenced an election. A Mr. Cobb was running against her husband. She described the bonnet she wore by discussing how she received it from

\footnotetext{
${ }^{59}$ Virginia Clay-Clopton and Ada Sterling, A Belle of the Fifties: Memoirs of Mrs. Clay of Alabama, Covering Social and Political Life in Washington and the South, 1853-66, (Tuscaloosa: University of Alabama Press, 1999): 90.

${ }^{60}$ Cashin, 348. 355-6, 357.
} 
another woman, "The little rustic girl of Alabama looked very winsome and blossomy in the pretty gewgaw, and I asked her impulsively if she liked it. Her confusion was sufficient answer, and I promptly presented it to her, on condition that she would give me her sunbonnet in return..." This fashionable impulse would prove fortuitous for her husband, "when Mr. Clay and I departed I wore a pea-green cambric bonnet, lined with pink and stiffened with pasteboard slats. I little dreamed that this exchange of millinery, so unpremeditated, and certainly uncalculating, was a political masterstroke; but, so it proved. ${ }^{61}$ Later, Mr. Cobb confronted Clay Clopton about the exchanged bonnets, as he told her, "I've got a crow to pick with you, Mrs. Clay," he began, " for that pink bonnet trick at old Aunt Hannah's!”62 Mr. Cobb, and Mrs. Clay, both referenced the bonnet as part of the reason Mr. Clay was successful. The fashionable choices of his wife were seen to have influenced the people. While this conversation occurred in jest it is significant that both men and women saw textiles as significant influencers.

Fashion had the power to distinguish class and race. Both women and men wished to dress in their best clothes during the war, and especially when seeing company, clothing mattered to the observer and the wearer. Women's clothing was often taken by invading soldiers. Textiles were just one of the resources that soldiers fought over. ${ }^{63}$ The Civil War changed the culture of fashion in the South based on a lack of funds and available materials. The antebellum

\footnotetext{
${ }^{61}$ Clay-Clopton

${ }^{62}$ Clay-Clopton, 90

The Entire Exchange:

"When, upon the train en route for the capital in the winter of '53, Senator Fitzpatrick insisted upon presenting the erstwhile triumphant politician, I took the long, flail like hand he offered me with no accentuated cordiality; my reserve, however, seemed not to disturb Mr. Cobb's proverbial complacency. "I've got a crow to pick with you, Mrs. Clay," he began, " for that pink bonnet trick at old Aunt Hannah's!"' And I have a buzzard to pick with you!" I responded promptly, "for defeating my husband!" "You ought to feel obliged to me," retorted the Congressman, continuing "For I made your husband a Senator!" "Well," I rejoined, "I'll promise not to repeat the bonnet business, if you'll give me your word never again to sing against my husband! That's unfair, for you know he can't sing!" which, amid the laughter of our fellow passengers, Mr. Cobb promised."

${ }^{63}$ Cashin, 340-343.
} 
South revolved around fashion. Cashin argues that many women saw this cultural change as a breakdown of their former society. ${ }^{64}$ This very emotional feeling toward textiles illustrates their immense importance. Even if only in anecdote, Clay Clopton illustrates that multiple people saw the bonnet as being influential.

With the outbreak of secessionist fever in 1860 , there was also an outbreak of homespun fabrics. Constance Cary Harrison was present for Lincoln's inauguration, and she remembered it through textiles. She recalled, "A terrible crush of people, ... woodsmen in flannel shirts and Sunday coats, great ladies of the administration, in line with struggling women and children hardly dressed or kempt for festal occasion. That was the reception where the curtains had pieces cut out of them for souvenirs by the backwoodsmen." ${ }^{65}$ Southern citizens wished to distance themselves from the North not only in government, but also in literature, and their textiles. A fervent campaign began to illustrate that Southern homespun might be fashionable, and even superior from foreign silks and fine fabrics. In the Richmond Daily Dispatch, immediately after the discussion of a young lady jilted by a beloved who decided to preach instead of marry, the correspondent wrote, "Suits of homespun clothes are becoming quite fashionable here, and it is thought that this style of dress will be bon ton with us at no distant day." ${ }^{\prime 66}$ It was as if Southern society, as shown by its newspapers, understood the textile consequences of seceding from the North quickly, that consequence largely being a forced change in what was fashionable textiles.

As it had during the Revolutionary War, the start of war prompted women throughout the South who had never touched a spinning wheel or loom take up the craft, making homespun an original Southern fashion. Virginia Clay Clopton wrote, "All over the South old spinning wheels

\footnotetext{
${ }^{64}$ Cashin, 354.

${ }^{65}$ Cary Harrison, 30.

${ }^{66}$ The [Richmond] Daily Dispatch, January 28, 1860
} 
and handlooms were brought out from dusty corners, and the whirr of the wheel became a very real song to us." ${ }^{67}$ The Abingdon Virginian reposted an article from the Clarkesville Chronicle discussion the "patriotic" ladies dressed in homespun, and asked all women to adopt homespun dress. They claimed, "There is no dress more becoming our young ladies in these war times than the above-They may prefer silks and satins, delaines and merines, and rig themselves off in jewelry like an Indian squaw — but beauty unadorned the most. Give us the girl in the plain calico dress, or, what is better, homespun. Throw your extravagance and pride away together, young ladies and remember what your grandmothers did in the revolution." 68 This article questioned the whiteness of women who refused to give up fine fabric for homespun by likening well adorned women to an "Indian Squaw." The paper also evoked the memory of the brave revolutionary women who traded their luxuries for homespun. Homespun became a distinctly Southern mode of dress, and it addressed patriotism and support of the state and Southern industry as opposed to Northern manufacturers.

Homespun was also a way for women to illustrate their support of the cause, regardless of status or birth. A letter from Williamsburg, Virginia appeared in the Richmond Daily Dispatch in order to praise a woman from the North who "Was the first of this place to put on homespun and go to church with it on, instead of silk. There are many more ready to follow her in this great work of freedom and right. The ladies are at work making coats and pants for soldiers around here." 69 The homespun trend extended to the best circles in Virginian society. The Staunton Spectator reported seeing the Speaker Pro. Tem of the House of delegates made from Staunton made cloth, as well as another member being married "and appeared at the altar in a full suit of

\footnotetext{
${ }^{67}$ Clay-Clopton, 223.

${ }^{68}$ The Abingdon Virginian, November 14, 1862.

69 “A Homespun Soldier, (in camp)" The [Richmond] Daily Dispatch, September 9, 1861.
} 
homespun, underneath the vest of which we venture to say, beats as true as a heart as there is in the Old Dominion.." ${ }^{\prime 0}$ Bridal clothes were not only meaningful to the bride: the delegates wedding was likely a large event, and the fact that such important men wore homespun to such public gathering is indicative of the importance of homespun to Southern identity. "The Northern goods are out of date, And since Old Abe's Blockade, We Southern girls can be content with goods that's Southern made We send our sweethearts to the war, But dear girls never mind. Your soldiers love will ne'er forget The girl he's left behind." Not only did this poem reference the wartime attraction of soldiers, but also their attraction after the war, "And when the sunny South is free, And fighting is no more, I'll choose me then a lover brave, From out that gallant bind The soldier that I love the best, Shall have my heart and hand." ${ }^{\text {11 }}$ This poem reminds soldiers that to find love and in order to find a wife to build a Southern household, a man had to be a soldier. In this song about the typical Southern girl, marriage and homespun were tied closely together, illustrating that Southern society connected marriage and homespun even if they were not completely aware of the meaning they placed on textiles and marriage. The song seemed to tell young Southern girls that as long as they continue to wear homespun and support the war effort, their sweethearts would return to marry them. Songs like these, and lyrics and stories encouraging girls to wear homespun and be loyal with their hearts to men fighting the war, seemed to promise Southern women a contract, they work with textiles as the government believed they should, and they would be married. Songs about homespun remained popular during the war. One ballad, published in 1866 proclaimed "Let vapid idlers loll in silk, Around the costly board; Give us the Bowl of Soup and milk, By homespun beauty poured." 72 In this

\footnotetext{
${ }^{70}$ Staunton Spectator, January 10, 1860.

71 "The Southern Girls Song," The Abingdon Virginian, January 29, 1864.

72 Staunton Spectator, September 25, 1866.
} 
section called natural beauty, it indicated that the homespun ideal remained strong throughout the war.

For many elite Southerners, it was difficult to reconcile the reality of wartime weaving and spinning with Antebellum ideas of appropriate work for elite white women. In many plantation households where enslaved people performed all of the previous rough textile labor, elite white women began weaving and spinning. Drew Gilpin Faust explains many husbands were not happy with their wives' new responsibilities. Will Neblett wrote his wife Lizzie "I do not like the idea of your weaving. It is mortifying to me, I wish you not to do it." 73 It was hard for husbands like Will to reconcile themselves to the new reality, their elite wives were no longer able in most cases to live idly. As Faust argues, this differentiation blurred the lines of race and class, and husbands were uncomfortable with the change in their wives' roles from residing in a place of domesticity to domestic manufacture. ${ }^{74}$ Elizabeth Fox Genovese makes a compelling argument regarding the plantation household being a place of domestic production in antebellum America. She argues that in regard to the stitching that was part of the mistress's daily routine in the plantation household that "In all of these instances, their relation to cloth articulated dimensions of their lives and their relations with others - dimensions of their identities."75 Genovese recognizes the great significance that antebellum Southern women placed on their textiles, and their skill with textiles, or the quality of work that their slaves produced. However, items stitched by slaves, regardless of the skill used to create them, were not valued as a craft. ${ }^{76}$

\footnotetext{
${ }^{73}$ Faust, 47.

${ }^{74}$ Elizabeth Fox-Genovese, Within the Plantation Household, (Chapel Hill: University of North Carolina

${ }^{75}$ Genovese, 120.

${ }^{76}$ Genovese, 138.
} Press, 1988). 
Many women struggled learning such tasks as weaving and spinning. Cary Harrison wrote of her experience when first learning to spin, "The cotton crop, unfamiliar to our eyes, was a beautiful one, from its blossoms of a delicate lemon tint, to the boll, opening to disclose a fairy fall of snow. We took our first lessons in spinning from an expert old darky woman in the 'quarter,' and also in weaving the stuffs required to clothe the small army of blacks on the estate." "77 Cary Harrison's reflections illustrate how distanced she was from cotton and cloth production. Mary Watkins, one plantation woman who relied on her slaves and others for much textile production, could not continue this process throughout the war, "Mrs. Dixon was here yesterday and she says she has woven five hundred yards of cloth this fall. Mama is pulling in a piece now and I am learning to warp...I have to go to Mrs. Dixon's to pay her for my weaving"78 While she had previously had all of her weaving done by an outside source, finding a weaver was more difficult as weavers were in higher demand during the war. Here, she claims she was learning to warp. ${ }^{79}$ She was beginning to learn to weave. Weavers were busy because of the constant need for cloth in plantations everywhere, war time scarcity meant that weavers services were valued for more than the creation of clothing for enslaved people, women in the war suddenly required weavers for much of their textile needs. Unfortunately for Mary Watkins, she was not entirely successful at the task. Just months later in March of 1862, she wrote, "Have not had the shirting for the negroes wove yet because I could not get the warp and now I don't know that I can get anybody to weave it." ${ }^{80}$ As Mary Watkins learned, textile creation was not easy. ${ }^{81}$

${ }^{77}$ Cary Harrison, 96.

${ }^{78}$ Mary Watkins, December 11, 1861, 52.

${ }^{79}$ There is very limited information about Mrs. Dixon. She was likely a woman who wove in order to support herself in her household, not a plantation mistress. Mary Watkins needed to learn to weave in order to clothe her household, primarily her slaves. Her household also needed textile items like blankets. Finer woven items would also be used for her own family.

${ }^{80}$ Mary Watkins, March 6, 1862, 67.

${ }^{81}$ While all Southern women were familiar with some type of stitching, economic status decided what women were familiar with before the start of the war. Elite women were likely more familiar with a needle and 
The institution of Southern marriage had to be bound to the new Southern Confederacy. Constance Cary Harrison remembers attending a war time wedding on Grace street that was "crowded with rusty uniforms." 82 "Richmond girls would not exchange the chance of receiving flying visits from Uncle Robert's boys in gray uniforms, however threadbare and smoke-stained from a hundred fights." 83 The breakdown of Confederate textiles added to the meaning they held. Homespun was not only important for nationalism within the Southern Confederacy, but it also changed love. Courtship rituals among the Southern elite continued to involve much pomp and circumstance, but silk, a traditional symbol of status, gave way to homespun for its patriotic value. For men, Confederate uniforms were expected. The attack on Fort Sumter launched a state of confusion. The Union was often discussed in rhetoric as a marriage, and secession was akin to a divorce: a permanent separation between husband and wife. When women transformed their bridal clothing to battle flags, they were wedding themselves to the new nation. The time of secession was a time of uncertainty. Textile sacrifice transformed, as men and women gave up luxurious fabrics for homespun, all of these sacrifices represented commitment to the South. Marriage changed with secession, and textiles illustrated the fact.

The Civil War changed marriages, distance forced couples apart, and economic hardship affected even the wealthiest of unions. As the war continued and the fabric of society became threadbare, the silk flags made from the bridal clothes of the Confederacy sustained rips and tears, some were captured by the enemy and lost their tassels. However, these flags were treasured. As they led men into battle, they were reminded what they were fighting for. The one

thread in order to create fine embroidery, or perhaps some mending and knitting. They would not have been familiar with weaving and spinning, as both were more closely associated with production. Weaving was done in order to create clothe, most likely garments for slaves. The clothe would then have to be sewn into clothing.

${ }^{82}$ Cary Harrison, 52.

${ }^{83}$ Cary Harrison, 85. 
man in the unit, who had married the woman who donated her bridal clothes, could carry his marriage into battle with him, as well as his wife's moral influence. Finally, the silk battle flags represented the end to many marriages, as the silk flag was often given to a woman whose husband had died fighting under it.

Construction in the time of secession followed deconstruction. In order to create a new Southern Confederacy, the union had to be disintegrated. In order to create a new Southern culture including a literary market, textile production, and other manufacturing, bonds with the North had to be broken. The same philosophy applied to Southern marriages. Wartime separation deconstructed Southern marriages. In order to wear their support for the cause, women tore apart their wardrobes to replace their silk dresses with homespun. In order to construct a battle flag made of bridal clothing, a wife would have to partially deconstruct what might be the most significant fabric she wore in her life. She would have had to accept the loss as she ripped out the seams that she might cut the flag pattern. Stitching was often associated with femininity, domesticity, and feminine affection, and all of these ideals were likely present in the minds of the wife and her friends who constructed the flag. They capitalized on the fabrics' meaning, as many of the ladies simply participating in stitching were likely also sending a husband to war to fight under that flag. However, after the fabric was constructed, it had to be circulated throughout the South to connect husband and wife emotionally, even while they were separated. 


\section{Chapter 2: Circulation and the Textile Exchange}

In a letter published in the Wheeling Daily Intelligencer November 22, 1861, one man, Billy, received a pair of stockings with his initials stitched into them. The letter indicated he was very thankful, because "A man may be bald-headed and its genteel [sic], but to be bare footed is ruination." The letter, though its tone was mocking, exemplifies the connection between textiles and love, "If there's anything in life worse than unrequited love, it's a sore heel." ${ }^{84}$ Unfortunately for Billy, after only one march he had ruined the silk stockings. Stockings were an important cultural symbol during the Civil War. Countless newspapers reminded women that it was their duty to outfit the barefooted soldiers. Love and companionate marriages were important symbols for Victorian Americans. For many soldiers and women waiting at home, a companionate marriage was part of their dreams for life after the war. Part of love, and an ideal marriage in the Civil War, was a wife who took care of the textile needs of her husband.

The Bond family resided in Virginia, and often exchanged letters and textiles. They had been married long before the war and had two children. Their letters exhibit the grand affection they had for one another, that was often communicated through the exchange of textiles. Bond wrote to his wife Elizabeth, "I want to get at it and fight it out and get back home and see my sweet wife and children and be there to stay and live in peace and not be always pestered to death about war." 85 The quote illustrates not only the affection they held for one another, but also the Bonds desperation to be reunited with his wife. Remaining connected was important, and letters, as well as the textile exchange, helped the couple do so.

\footnotetext{
84 “A Laughable Letter from the Army,” The [Wheeling] Daily Intelligencer, November 22, 1861.

${ }^{85}$ Henry Bond to Elizabeth Bond, May 15, 1861, Bond Family Correspondence, Virginia Historical Society.
} 
A Southern girl was supposed to manage the textiles of her husband. The following poem that was republished in multiple Southern newspapers exemplified the importance of having a young Southern girl as a wife, and the theme of patriotic stitching was very present. "Her handkerchiefs are white as milk; Her skirts are white as snow; Her slippered feet are small and neat, And always "on the go..." My linen has a glossy white, More pure than ever shown...She knits me stockings, makes me shirts, And darns up all my rents, And saves me half of what was once My bachelor expense. Now all you crusty bachelors With life's great battle sour, Get a wife and settle down, And play the fool no more!" 86 The poem successfully encourages unmarried men to take a wife, as the "expense," was not what one would imagine. When the poet refers to the girl's skirts being "white as snow," it seems to be an illusion to the purity of Southern girls. For Southern girls, the poem represents the traits, many of them associated with textiles, that would help them get a husband. In a song encouraging men to marry, textiles are prominent because the duties of a wife were so closely associated to textiles.

One of the more popular hobbies women engaged in during the Civil War was knitting. Anne MacDonald argues that in the South, women wished to knit primarily for their husbands and loved ones. However, spinning, weaving, and knitting were also done for men from different states, especially when it became more difficult to exchange goods during the war. MacDonald argues that women knitted to keep busy at all times, even when at rest, because gendered ideals required them to never have idle hands. Women who could not knit at the start of the conflict typically had expanded their stitching abilities by the end. MacDonald tied the women of the Confederacy knitting to the women of the revolution. Just like their revolutionary mothers,

86“My Wife," The South-Western, February 27, 1861. 
Confederate women were knitting stockings for their men at war, and also dealing with homespun items. ${ }^{87}$

The labor wives did for their husbands gave the objects they sent life and meaning for the soldiers, meaning the objects themselves affected the war by raising soldier morale. James McPherson argues that particularly for married soldiers, morale was tied to home. McPherson specifically mentions letters causing morale to either raise or plummet. Soldiers often rationalized their commitment to their cause because they were protecting their own home and loved ones. However, this was a far more difficult argument to make when their wives sent letters attempting to describe to their husbands the economic deprivation and loneliness they had to deal with while they fought in the war. ${ }^{88}$ McPherson does not include textiles in his analysis, but textiles also had a great influence on the morale of soldiers fighting the war.

Receiving a gift from home not only gave a soldier a stocking that might keep them warm but this gift also showed support from the home front. Textiles often held meaning for the soldiers receiving them because they reminded them of home. The spaces throughout the home took meaning from the labor done within them. Soldiers often wrote of the joy they felt when they received items from home, particularly textiles their wives had made. Bond, after receiving more clothing from his wife, wrote, "I received my comfort and gloves they're the best I ever saw in my life and I am highly pleased with them... you have kept serving me things until I am about the finest dressed man in the camp and the ladies fall in love with me everywhere I go, sometimes the boys pass me off for a single man and have near fun." ${ }^{89}$ The gloves gave Bond a

\footnotetext{
${ }^{87}$ Anne MacDonald, No Idle Hands: The Social History of American Knitting, (New York: Ballantine Books, 1988): 119-126.

${ }^{88}$ James McPherson, For Cause and Comrades: Why Men Fought in the Civil War, (New York: Oxford University Press, 1997): 133.

${ }^{89}$ Henry Bond to Elizabeth Bond, No Date, Bond Family Correspondence, Virginia Historical Society.
} 
tangible reminder of home. The teasing remarks in the message emphasize the sentimental nature of the exchange. Gaston Bachelard argues that labor, like housework, is what gives objects real life, "from one object to another in the bedroom, housewifely care weaves together the very distant past and the new day. The housewife awakens the sleeping furniture." 90 Textiles sent by wives to soldiers took great meaning from how the woman made it. Glenna Mathews also sees empowerment for women in the space of the home, but through ideals of domesticity. The "cult of domesticity" was tied closely to the ideal morality meaning that women in the realms of domesticity were expected to be the moral influence, and as a result domesticity empowered women. ${ }^{91}$ While this narrative primarily emphasizes middle class ideology and experience in the North, the meaning of housework, like stitching, was essential to how men and women thought about themselves and each other.

Women used the textile exchange to help them navigate the environment of the war. In Mothers of Invention, Drew Gilpin Faust presents how Lucy Wood was one of the thousands of women who joined a female organization in the South. Faust describes how Wood had some difficulty in her courtship with her love, Waddy, at the start of the conflict because of her attempt to discuss the conflict with him with her own strong political views. However, her dedication to sewing for the soldiers emphasized her place as the "helpmate" of man, and thereby put her in her correct place. Lucy Wood, like countless other women in the South, saw this work as important. She claimed "our needles are now our weapons and we have a part to perform as well as the rest." ${ }^{\prime 92}$ For Wood's relationship, the domesticity of sewing for the conflict created the

\footnotetext{
${ }^{90}$ Gaston Bachelard, The Poetics of Space. (Boston: Beacon Press, 1969): 74. (Quote also featured in Auslander, 1021.)

${ }^{91}$ Glenna Mathews, Just a Housewife: The Rise and Fall of Domesticity in America, (New York: Oxford University Press, 1987): 35-65.

${ }^{92}$ Drew Gilpin Faust, Mothers of Invention: Women of the Slaveholding South in the American Civil War, (Chapel Hill: University of North Carolina Press, 1995): 24.
} 
imagery that she was residing in her proper place. However, by sewing for the conflict, regardless of what she said, she was participating in political action. Henry Bond often wrote his wife to tell her of his weight, so she might understand his size, he wrote affectionately "Oh I tell you I am a whopper and am still fattening. I shall be 175 lbs. by Christmas," and he later wrote of each item of clothing she sent that "it is the best I ever saw." ${ }^{93}$ Whenever he received clothes made by Lizzie he consistently assured her they were the best possible. While Lizzie's letters are not available, her husband's letters are indicative of how assured she might feel that she was a part of the war effort. She was clothing her husband and remaining connected to him even while they were separate. The stockings gave both members of the couple comfort.

The exchange of textile in the Civil War was utilitarian, but it was often expressed in terms of love. Karen Lystra studies romantic love in the nineteenth century, and argues that romantic devotion was based in secrecy, as opposed to the public institution of marriage. In order to study courtship and romantic love, Lystra turns to letters. She argued Victorians "believed this love was essentially a mystery, at its essence beyond analysis." ${ }^{94}$ This mysterious force remained important to Victorians, however, during the Civil War and in marriage as well. Lystra, however, argues that while divorces increased following the Civil War, "the basic framework of romantic love remained intact throughout this period." ${ }^{95}$ While this is largely true, romantic love during the Civil War altered due to economic and violent pressures. Letters between married couples during the Civil War exhibited the same tendencies as letters of courtship as opposed to only the realities of life. ${ }^{96}$

\footnotetext{
${ }^{93}$ Henry Bond to Elizabeth Bond, No Date, Bond Family Correspondence, Virginia Historical Society.

${ }^{94}$ Lystra, 3, 6 .

${ }^{95}$ Lystra, 8.

${ }^{96}$ Lystra, 10.
} 
For Victorian couples, love was about self-revelation. Couples in love were expected to share all of their deepest emotions and feelings. While masculinity required men to be reserved, in private to their potential partner they were expected to be completely open. Pet names, or possessives, "symbolized an exclusive circle of sender and receiver, affirming a couple's emotional intimacy and mutual identification." 97 The Bond family often referred to each other in affectionate terms as well as possessives. Bond most often referred to his wife as "my dear wife," and called her and the children "my little family."98 The separation was poignant for the Bond family, "Although I am 200 miles from you my mind wanders back to old before to our little home at the Walnut Grove and seemed that if we had peace and I could be with you that I could be satisfied with almost any kind of a home." ${ }^{99}$ Bond longed for peace so he might be reunited with his wife.

The separation couples were forced to endure emphasized the extent of their love. For Victorian couples, love was synonymous with pain. Pain was representative of the connection between to people. Lovers were supposed to feel pain when they were separated. ${ }^{100}$ The Bond family acutely experienced the pain of separation. Bond wrote his wife, "I want to get at it and fight it out and get back home and see my sweet wife and children and there to stay and live in peace and not be always pestered to death about war." ${ }^{101}$ Both sides of a Civil War couple were able to "inflict pain" but also intense pleasure. Those were the dynamics of love. However, couples expected to be happy when united with their love, but the Civil War often made that difficult. "I received yours of the 7th with which I am much pleased it gave me much satisfaction

\footnotetext{
${ }^{97}$ Lystra, 20.

${ }^{98}$ Henry Bond to Elizabeth Bond, Dec. 23, 1861, Bond Family Correspondence, Virginia Historical Society.

${ }^{99}$ Henry Bond to Elizabeth Bond, July 7, 1861, Bond Family Correspondence, Virginia Historical Society.

${ }^{100}$ Lystra, 50-51.

${ }^{101}$ H.L Bond to Elizabeth Bond, May 15 1861, Bond Family Correspondence, Virginia Historical Society.
} 
to receive a letter from ones old companion although I am far away in the army my thoughts often wonder back to the loves ones at home," Bond continued to say "when I know that it is out of my power to be with you and the children," Bond looked "to the time when I can come home and remain there." 102 Bond was desperate to be reunited with his wife, and the separation was painful for him.

Morality, particularly of the husband while he was away, was a frequent topic of discussion among Civil War couples. Lysta also argues that in the Victorian Era, men were able to applaud intelligence in women, particularly as their sexual identity was defined by how morally and intelligently they raised their children. However, as women displayed intelligence, letters illustrate how women felt it necessary to restore male dominance. ${ }^{103}$ Bond clearly understood his wife's moral influence and intelligence, he wrote that her letter was "very interesting," and that "I appreciate the advice you have me in the letter and you may rest assured that I have not forgotten the promise I made you when parting with you. I have thought of it many times, but you wright very discouragingly to me you wright like you are sure you will never see me...you must recollect that there have been millions of men been to war that returned home safe," However, Bond went on to assure his wife in a way that illustrated his hope for a short war "It appears to me that I will not only not get killed but will not get into any battles. I have been trying to get to come home to see you ever since I have been down here have not had the chance." ${ }^{104}$ Already in 1861 Bond's wife was discouraged in regards to the outcome of the war. However, in order to do her part, she continued to send Bond as many textile items as she could, from stockings to uniforms in order to show her husband her support and affection. Lystra

\footnotetext{
${ }^{102}$ Henry Bond to Elizabeth Bond, September 16, 1861, Bond Family Correspondence, Virginia Historical Society.

${ }^{103}$ Lystra, 144, 128, 138.

${ }^{104}$ H.L Bond to Elizabeth Bond, May 15, 1861, Bond Family Correspondence, Virginia Historical Society.
} 
argues that the dramatics of courtship were supposed to recede into contented ness for married couples. While love was affirmed in marriages, it was not as populated with feelings. "marital exchanges about love seem almost to be affirmations of past accomplishment." ${ }^{105}$ However, during the Civil War, the uncertainty of the future was ever present in the minds of couples.

The Bond family experienced the typical pressure on their war time marriage: Lizzie feared for her welfare, and showed concern that Bond would take up bad habits while away from home. Lizzie was often worried about "an insurrection of the Negroes," but was assured by her husband "you need not give yourself any uneasiness about that don't you know that we could get there in a day and a night from here...they can't shoot nor stand to be shot at so you may rest yourself entirely easy about that." ${ }^{106}$ Bond often wrote to Lizzie above all others. He often criticized her for not writing enough, and then asked her to make apologies to his parents because while he was sure to write Lizzie as much as possible, sometimes as much as 3 letters to Lizzie to her one. ${ }^{107}$ However, even at a distance the Bond marriage remained romantic. In one letter Bond was sure to inform his wife that claims that he was a drunk at Christmastime were untrue, but then alluded to their romantic relationship, "I am proud to hear that my dear Lizzie is fattening I want you to continue to fatten until you get to be as large as you was when we were married so I will have an armful again." ${ }^{108}$ Lizzie was also often jealous of her husband. "You spoke of your mama saying that you would be forgotten by me as I spoke so much about the young ladies, while I have considerable fun with some of the young ladies there is not an hour passes over but what I think of my dear Lizzie so you must not give yourself any uneasiness

\footnotetext{
105 Lystra, 205.

106 The Bond Family Correspondence, November 30, 1862.

107 The Bond Family Correspondence, July 7/9, 1862.

108 The Bond Family Correspondence, January 19, 1862.
} 
about being forgotten," Bond continued to placate his wife by promising, "one who thinks so much of you I could not love another as I do yourself." 109 The Bond family exhibits a typical discourse of love in their letters, and this love was supplemented by textiles.

The letters the Bond family exchanged illustrate how they used textiles in order to continue Victorian patterns of love even when separated.

Dear Lizzie....if I to live to get through with this 12 months I will never volunteer again until all the young men die....Y You wanted to know whether I needed my pants... I will let you know when I need them the pants I have will last me until Christmas at which I expect to be at home with my sweet Lizzie ... I pledge you my word and honor that $\mathrm{i}$ have never done a single thing but what I would be perfectly willing you should see and know since I have been in camps and never intended I should remain here 12 months. ${ }^{110}$

This letter is indicative of the affection within their marriage. Henry Bond made it clear how much he relied on his wife's' letters. He emphasized the importance of his family and his need to be near them, but then immediately after begins discussing his textile needs with his wife. He then emphasized he was a good husband even when far from home. These words represent many traditional aspects of Victorian love. While Lizzie's letter is not available, it seems she asked her husband probing questions in order to reaffirm his desire for her and her influence in his life. This letter also illustrates that Lizzie continued to do the necessary textile work to ensure her husband's comfort.

While Lizzie Bond was assembling textiles for her husband's comfort, she was also likely a member of a ladies' society that organized to supply not only loved ones, but units from their own county, or even the entire Confederate army. Mary Dickison made a battle flag for her husband's unit, but her textile contribution to the war effort did not end there. Soldiers' wives

\footnotetext{
${ }^{109}$ Henry Bond to Elizabeth Bond, No date, Bond Family Correspondence, Virginia Historical Society.

${ }^{110}$ Henry Bond to Elizabeth Bond, No date, Bond Family Correspondence, Virginia Historical Society.
} 
throughout the South quickly began to outfit their husbands for the war effort. They knit stockings, mended pants, and did what they could to ensure their husbands were outfitted in a top-notch style. A pair of stockings was a strong materialization of love to a soldier forced to be separated from his wife for what might be the first time. Textiles were a physical and utilitarian way for married couples to remain connected throughout the Civil War. In order to participate in this phenomenon, Dickison joined the local ladies group, known as the "Thimble Brigade." She wrote that, "With grateful hearts we labored to provide comforts for the brave soldiers, who around their campfires were keeping watch for us."111 The group made thirty pairs of pants for soldiers in one month, and that was on top of knit stockings women in the group also knit for their husbands and loved ones. The groups' constitution said, "Resolved, That as the season is approaching when warm clothing will be needed, as a society, we will help to meet this requirement. With busy fingers, will we ply the needle, grateful that we, too, can be up and doing our part in the noble cause for which our fathers, husbands, sons and brothers are battling." 112 This statute emphasized that the women understood the armies' struggle for supplies. Women also felt that it was their duty to supply the army. While their male loved ones followed their duty by fighting in the war, women completed their duty by stitching for the army. Mary was the secretary of recording and correspondence. Countless other women also participated in the textile exchange this way.

Textile creation organizations flourished during the war. Newspapers played a great role in encouraging women to organize for the war effort. The Staunton Spectator, again publishing a piece from Augusta, continued to encourage women to create soldiers aid societies to supply their loved ones. In one article they suggest ladies aiding soldiers would be an act of leisure,

\footnotetext{
${ }^{111}$ Mary Dickison, Dickison and His Men, (San Marco Bookstore, 1984): 161-162.

112 Dickison, 164.
} 
"These societies would be pleasant to the members, as they would not only have the pleasure of good company, but would enjoy the 'luxury' of doing good." 113 While knitting and stitching was work, it could also be considered a leisure activity if women were stitching while socializing. Women viewed their work for their husbands and for the war effort differently. Ladies like Lizzie Bond, Mary Dickison, and Mary Watkins likely found their textiles aid groups as a great way to socialize during the war while their husbands were away. Knitting even became a competition amongst ladies, "One lady remarked when preparing a package of clothing —-I know I will knit more socks than any one,"- - but she soon discovered three families, one just a widow, knit 30 pairs. ${ }^{114}$ These ladies, both members of the Zion's Church Society, were determined to be the most patriotic, and supply not only their loved ones but also the entire Confederate army. The Richmond Daily Dispatch often reminded women that the Young Men's Christian Association was happy to supply wool for knitters, so even those that were not affluent enough to purchase yarn might knit for soldiers. ${ }^{115}$ For women who enjoyed social activities, knitting and stitching was sometimes considered an act of leisure. However, stitching might also be considered work. Many women supported themselves during the war by stitching. Even for those that knitted solely for their loved ones, keeping them adequately supplied with textile materials was no easy feat.

While the stockings would be given to soldiers who were likely strangers, the ideals of romantic love were alive in the action of knitting the stockings. Newspapers often claimed that women would happily supply the soldiers with their needs. The Staunton Spectator, again republishing news from Georgia, recorded that the ladies of Augusta, upon learning the

${ }^{113}$ Staunton Spectator, March 10, 1863.

${ }^{114}$ Staunton Spectator, March 10, 1863.

${ }^{115}$ The [Richmond] Daily Dispatch, November 301863. 
stonewall brigade was without socks, offered to knit for them as "They do not regard working for the soldiers as a labor, but as a pleasure. For that purpose, they work con amore, it being with them a labor of love, and we can assure them it will not be "Love's labor lost." 116 The women, and the gentleman writing the article, clearly articulated that the act of knitting was closely associated with love.

The knitting of stockings was an important phenomenon, as evidenced by how often knitters were mentioned in their local papers. They were often not only mentioned, but praised for the quantification of patriotism in how many stockings were knit. One paper praised the ladies of Albemarle County. Beginning in December of 1863, the ladies, "have had wool carded and spun, and nine hundred pairs of socks knit for the government, and in addition have given away two hundred pairs of their own..." The newspaper then continued to emphasize, "the ladies of Albemarle, it will be seen, are not behind their fair sisters in other counties, in deeds of love and kindness to the brave men who have taken their lives in their hands and gone to the fields of battle to defend the homes and firesides of the people."117 This illustrates the competitive nature of stocking the army with stockings. Ladies were expected to match the contributions of other areas of the South. This materialization of love was a way in which the ladies of the South showed their love and support, and ladies did not want to be seen as less patriotic than other areas of the South.

Henry Bond often wrote to his wife about his desire for homemade textiles: they were a source of pride for him, so he knew what he wanted from his wife. When he asked his wife to make him a pair of grey pants, he was very particular in his request, "not any kind," and "be sure

\footnotetext{
${ }^{116}$ Staunton Spectator, March 1, 1864.

117 Staunton Spectator, May 3, 1863.
} 
and make them with something strong." 118 While the textiles these couples exchanged did not exhibit the same overt symbolism present in battle flags made of bridal clothes and ladies dresses, these textiles represented a wife's support for the war effort and were tangible forms of love and remembrance for husbands in the midst of battle. For the Bond family, a knit pair of stockings had much greater meaning. Henry Bond wrote his wife, "you must knit me them Stockings. I should be so proud of them." ${ }^{119}$ Henry Bond desperately wanted to have more of his wife's knitting. A pair of stockings reminded him of home, his wife's love, and her support for himself and the war effort. The same pair of stockings would give Elizabeth Bond a way to show her support for her husband and the Southern cause, as well as care for her husband while he was away.

The gifts of textiles were often accompanied by reminders for her husband to avoid revelry and remain moral, allowing her to continue her domestic duty while her husband was away. This is indicative of the sentimentalist nature of love in the Civil War. A large part of the meaning and use found in textiles came from the sentimental nature of a loved one laboring for the soldier, particularly a soldiers' wife. While socks were knit by both loved ones and strangers for the soldiers, having a loved one supply necessary textiles for army life was preferred. In one story from the Atlanta Register republished by the Staunton Spectator, a solider received a pair of knit socks from the Georgia Relief fund. The article states, "Fortune favors the brave"— so he drew a splendid pair of well-knit wool socks" knit by his mother, "and I have no doubt he appreciates them more than the possession of a dozen pairs knit by strangers." 120

\footnotetext{
${ }^{118}$ Henry Bond to Elizabeth Bond, January 30, 1862, Bond Family Correspondence, Virginia Historical Society.

${ }^{119}$ Henry Bond to Elizabeth Bond, Sept 16, 1861, Bond Family Correspondence, Virginia Historical Society.

120 Staunton Spectator, March 29, 1864.
} 
Most women participated in the knitting for the soldiers, even if their husbands were waging war in politics rather than battle, including two of the most commonly cited Civil War women, Judith McGuire and Mary Chestnut. Judith McGuire claimed that knitting was a "soothing occupation [that] helped our perturbed spirits to be calm."121 As she observed women knitting for the soldiers, she wrote, "The ladies [are] all busily knitting for our soldiers — oh, that we could make them comfortable for the winter!"122 McGuire clearly felt that by knitting for the soldiers, whether husbands or local regiments, women were making a contribution to the war effort, and politically supporting the war effort. She, like many women, felt "regret that we did not learn to spin and weave." 123 Mary Chestnut also participated in knitting for the soldiers. She wrote "I do not know when I have seen a woman without knitting in her hand. Socks for the soldiers is the cry." ${ }^{124}$ Chestnut referred to the widespread outbreak of knitting during the conflict.

While men fought the war, women knit. Chestnut went on to say, "One poor man said he had dozens of socks and but one shirt. He preferred more shirts and fewer stockings. We make a quaint appearance with this twinkling of needles and the everlasting sock dangling below."125 While most respected how quickly women wished to support the war effort, it seemed the most women could do was knit stockings, which was not so useful when every soldier had an abundance of stockings but no pants or shirts. Newspapers included messages for women, encouraging them to knit, but also how to knit stockings correctly for their soldiers. "Get large needles and coarse yarn. Cast on seventy-eight stitches, and knit the leg ten inches long before

${ }^{121}$ Mary Chestnut, A Diary from Dixie, (New York: D. Appleton and Company, 1905): 122.

122 Judith McGuire, Diary of a Southern Refugee During the War, by a Lady of Virginia 1867, (Lincoln: University of Nebraska Press, 1995): 166.

${ }^{123}$ McGuire, 173.

${ }^{125}$ Chestnut, 113. 
setting the heel, which should be three and a half inches long, and knit of double yarn, one fine and one coarse, for extra strength. The foot should be eleven or twelve inches long." ${ }^{126}$ These directions might be a reply to a simple request for patterns, but also illustrated that some ladies struggled to complete knit stockings.

The sharing of textiles was not something that occurred in only one direction, Soldiers also sent gifts home to their wives. While they likely did not make the items themselves, they typically worked hard to find them or have them made. These items were tangible signs of love. Mary, as she was preparing to yet again send her husband more clothing, wrote, "Will send your brown pants as soon as I can....I was surprised yesterday by a bundle containing two neat, pretty calicoes. I need not tell you. . .how much I thank you. ... You are too thoughtful and kind to me. ...You displayed excellent taste in your selection of dresses, they suit me exactly and when you come home next time you can expect to see me dressed up in one of them." ${ }^{127}$ The pride and contentment Mary felt upon receiving the dresses practically jumps off the page. Textile gifts contributed to keeping their marriage strong, and ensuring that the couple remained content even when forced to endure the long separation of war. Elizabeth Bond was at one point during the war given clothe by her husband to make herself a dress. While this item was not for her husband, he still exhibited great pride in her accomplishment and used it to shower her with praise, "You wanted to know whether I was going to Volunteer again now you may rest assure that I never will volunteer again until I come home and not then until I see. I am sure to be drafted so I solemnly promise you Lizzie your new dresses are pretty I have showed it to several ladies and they make a great fuss over it and say they wish they could see you say they know you

\footnotetext{
126 "Stockings for the Soldiers," Staunton Spectator, November 19, 1861.

${ }^{127}$ Mary Watkins, April 22, 1863, 184.
} 
are smart and pretty." ${ }^{28}$ This illustrates that textiles did not only represent comfort for soldiers, but also the feelings of affection and pride they had for their wives.

Other Civil War couples went into great detail in regards to the clothing they had and received. For Thomas and Harriote Taliaferro, conversation often revolved around textiles. Taliaferro was able to provide for his wife by making do with his current clothing items as opposed to asking for more so his wife might use clothe she acquired for herself. He wrote his wife, "I am perfectly comfortable and do not need any clothes of any sort." ${ }^{129} \mathrm{He}$ went on to describe the clothing he had, "I have 4 flannel shirts 2 you made $2 \ldots$ put away for summer...4 thick shirts, 2 coats, 2 great coats, 4 of my own blankets... a shawl, making 8 blankets + a shawl for my bed, 6 plan good yarn socks, 2 pair boots, 3 pairs of drawers, 1 pair pants, and the splendid pair of gloves." He then claimed that the clothing he had "was... all I needed to make me perfectly comfortable. I do not want the clothe." 130 Taliaferro recognized his wife was in need of textiles as much as he was, and even at a distance wanted to ensure her comfort. The Taliaferro letters were often filled with conflict due to their separation, but through textiles Mr. Taliaferro romantically pleased his wife.

While many women knit for the war effort, Mary Watkins instructed others to knit for her husband, and tasked herself with ensuring he had all of the textile items he needed. Textiles were an essential part of Mary and Richard Watkins wartime marriage. The Watkins were an elite Southern couple who wrote to each other throughout the war. They had two children at the start, and one more after Richard came home on furlough. Richard was close enough to Richmond and

\footnotetext{
${ }^{128}$ Henry Bond to Elizabeth Bond, Jan 19, 1862, Bond Family Correspondence, Virginia Historical Society.

129 Thomas Seddon Taliaferro to Harriote Hopkins Taliaferro, Taliaferro Family Correspondence, January 15,1864

${ }^{130}$ Thomas Seddon Taliaferro to Harriote Hopkins Taliaferro, Taliaferro Family Correspondence, January 15, 1864,
} 
Mary that he was able to send home clothing that needed mending and pick up new clothing made by his wife fairly often throughout the war. In Mary's case, her work involved instructing others to construct garments for her husband, whether it was her husband's sister or if it was the couple's enslaved people. ${ }^{131}$ In December 1861, she wrote that "Patty is knitting you a vizor to keep your head, ears and throat warm while you are standing guard. I think it is just the thing for a cold, snowy night, if it does not obstruct your hearing..." ${ }^{132}$ Lizzie Bond also sent her husband's gifts through other people, such as when she had her mother mend and send some of Henry Bond's clothing to him December 23, 1861. He was very appreciative, and wrote back "I think a great deal of my drawers + shirts as they will add very greatly to my comfort." 133 The exchange of textiles was very much an aspect of spousal caring. Mary worried about Richard, and vice versa. "I am very much afraid you will take a cold going back into a tent in this weather." ${ }^{134}$ By sending Richard items like socks and blankets, she was ensuring that he would be warm when enduring the winter.

The exchange of textiles' primary purpose was the comfort of the soldiers and their wives at home. Women knit and stitched for their husbands and suitors because they knew their loved ones were suffering while they were so far away from home. When husbands wrote home to their wives, most tried to paint a portrait of health and well-being, however, husbands often honestly wrote their wives about the state of their health. For women, in order to aid their husbands, they knit and stitched so they might be as warm and comfortable and as healthy as women could possibly make them while they were separated. When Bond had an attack of the

${ }^{131}$ Richard Henry Watkins, Mary Purnell Dupuy Watkins, and Jeff Toalson. Send Me a Pair of Old Boots \& Kiss My Little Girls: The Civil War Letters of Richard and Mary Watkins, 1861-1865, (New York: Universe, 2009).

${ }^{132}$ Mary Watkins, December 4, 1861, 50.

${ }^{133}$ Henry Bond to Elizabeth Bond, No Date, Bond Family Correspondence, Virginia Historical Society.

${ }^{134}$ Mary Watkins, February 6, 1862, 62. 
flux, his wife was extremely worried, and soon sent him more clothing in order to keep him warm, even though bond assured her the attack was slight and he was really in "first rate health." 135 So while the textile exchange primarily benefitted the comfort and health of the soldiers, the emotional and sentimental impact of the textiles were essential.

When soldiers wrote home discussing their lives, they often used sensory examples, many of which included the textiles. ${ }^{136}$ Women sitting at home could picture their husbands' circumstances when he described being warm in his overcoat and the quilt she had sent him, and feel his despair when he wrote of how wet his blanket was and how miserable his situation was. Richard Watkins wrote his wife in February 1863 that General Lee himself gave him a furlough so he could once again be with his wife. Unfortunately, he was disappointed when he woke up and was once again lying in a wet blanket. ${ }^{137}$ Earlier in the war, he had complained that " $[\mathrm{t}]$ he weather is so cold that we all have to sleep with our clothes on. I do not think that I have taken mine off except for the purpose of changing my underclothes for two months excepting once or twice...I need a pair of coarse heavy oversocks. Can you not make Neely knit them[?]" 138 Richard used vivid imagery involving textiles when he was describing troubles he had while fighting the war. He most always discussed how he was never without clothes, and his blankets are wet, allowing his wife to picture his circumstances. Mary Watkins also used textile imagery to describe her melancholy. In August 1862, she wrote that "My darling husband, I feel so lonely today....came in the house and put away your clothes." ${ }^{139}$ While this clearly conveys miserable feelings, soldiers and their wives also used textiles to convey their own comfort, or to give their

\footnotetext{
${ }^{135}$ Henry Bond to Elizabeth Bond, Dec 2, 1861, Bond Family Correspondence, Virginia Historical Society.

${ }^{136}$ Mark M. Smith, The Smell of Battle, the Taste of Siege: A Sensory History of the Civil War. Mark Smith in his work argues that the Civil War was an unique experience due to sight, touch and sound. While his book does not specifically address the feeling of textiles, they may be applied to his methodology.

${ }^{137}$ Richard Watkins, February 19, 1863, 168.

${ }^{138}$ Richard Watkins, December 7, 1861, 51.

${ }^{139}$ Mary Watkins, August 20, 1862, 115.
} 
loved one an understanding of their circumstances. In October of 1862, Mary wrote that "I have undressed, put on my wrapper, and made myself comfortable." ${ }^{140}$ In this way, Mary not only informed her husband of what she is doing, but she also provided a quaint image of home he might hold onto while he was away.

In order to provide the most comfort to their husbands and suitors, wives could not only knit items like socks, but they also needed to supply them with uniforms. The Charlottesville Review wrote about one from their county heading to Harpers Ferry realized "that he would want a "suit of clothes, '.... The ladies of the town, with characteristic readiness, have gone to work for the soldiers uniforms, tents and knapsacks will be provided as fast as their gentle, but willing hands can prepare them." ${ }^{141}$ This selection from the newspaper was the Southern ideal. As the Southern government struggled to come up with uniforms for soldiers, women and local counties felt it was their duty to outfit their soldiers. This duty was most poignant with the wives of the men travelling to war, especially because it would be their husbands who would be freezing far away from the warmth of home. Newspapers were active participants in calling ladies to action, encouraging them to clothe their loved ones in war, but also the entire Confederate army. The Abingdon Virginian published, "Winter is near at hand. Our army, a large one, is in want of clothing. It is naked. It has suffered beyond computation. It has achieved wonders-everything but miracles-It cannot suspend the laws of nature. It has beaten the enemy on every important battlefield; but it cannot stay or drive back the frosts of winters. To this enemy it must succumb unless It is fortified against it." To begin with, the letter was free with its praise for the Confederate Army, calling their actions miraculous. However, while the army was without fault, the Confederate government has irrevocably failed to supply the needs of the miracle working

\footnotetext{
${ }^{140}$ Mary Watkins, October 9, 1862, 141.

${ }^{141}$ The[Richmond] Daily Dispatch, April 27, 1861.
} 
army. "The Confederate Government, I fear is inadequate to the task. It is devolved upon the states and the people to come to the rescue of the army, and come at once. I make this following suggestions....The courts could, therefore, order the purchase of leather and contract for the making of the shoes. They could also purchase wool, and have the socks knit." This letter to the editor is indicative of the propaganda directed toward ladies to encourage them to busy their needles. However, instead of asking the government to be more successful in its drive to clothe the army, the letter shifts the responsibility toward Confederate ladies. This article was not even a call to action for women, it was a plea for the Confederate government to begin giving Southern women the job of clothing the army, for the women would do a far better job than the federal government. "The ladies would knit them without charge. If any charge was made, it could and ought to be paid. ${ }^{142}$ Interestingly, the letter also values the work the women would do and states they might be paid for their efforts.

The Confederate Government was part of the reason women were so encouraged to provide uniforms for their husbands and the general soldiers of the Confederacy, the government asked women to supply the soldiers when cries of barefeet arrived. According to Thomas Arliskas, Confederate Uniforms were not standardized during the war, and while some regiments managed to clothe themselves entirely in one cohesive uniform, units tended to have a rag tag assortment of homespun, finer fabrics, or even blankets. Arlsikas separates the war into three periods of uniforms. In the early period, Confederate soldiers were expected to find their own clothing, but would be reimbursed for the value later. Early Confederate uniforms were created by ladies aid societies in a variety of styles, so there was no one uniform. The first and second great appeals were to furnish clothing for the soldiers. When the government believed, they

${ }^{142}$ The Abingdon Virginian, October 31, 1862. 
would not be able to, they called for civilians to furnish as much cloth for the army as possible. 143

Newspapers were quick to tell women it was their duty to supply the soldiers fighting the war. The Vicksburg Whig wrote "Almost every day we hear of some patriotic deed of the ladies of this city, who... have been so untiring in their devotion to our common cause," the paper describes women "cutting up their Balmoral skirts for trimmings for the soldiers' uniforms. The stripes were carefully cut out and used for trimming the pantaloons and coats and every part of the garment was worked up onto trimming for some part of the uniform." 144 This indicates that women were so devoted to their cause they were willing to cut up skirts to ensure their loved ones and other soldiers were well taken care of. Churches, throughout Virginia and the rest of the South, often held meetings at which ladies could have social time and also support their cause. One meeting at St. Paul's church that took place between 10 and 3 advertised, "By a resolution of St. Paul's Church Sewing Society, all the ladies of the congregation are requested to meet at the lecture room of St. Paul's Church today (Thursday) At 10 o clock for the purpose of having their assistance in making clothes for the companies not yet uniformed. Companies are requested to send their work between the hours of 10 and 3."145 These newspapers attempt to make it easy for women to contribute, and also illustrate exactly how widespread in culture women making uniforms for soldiers was. This was an expectation in society.

When women were not able to illustrate their love for their husbands by clothing them, their town and other women in the South worked to make it so their husbands were clothed. In

143 Thomas Arliskas, Cadet Gray \& Butternut Brown: Notes on Confederate Uniforms, (Gettysburg: Thomas Publications, 2006): 6, 13.

${ }^{144}$ Richmond Enquirer, November 26, 1861.

145 The [Richmond] Daily Dispatch, May 13, 1861. 
October of 1861 in particular, depots were set up throughout the South where clothing could be left, and if it was for the general army the giver might be reimbursed in war bonds. While the uniforms were not uniform, the First Great Appeal did a great deal for keeping the army in winter supplies. The appeal was especially effective when compared to the efforts of the quartermaster to furnish uniforms meant with resistance from the states when attempting to utilize all textile mills as well as trouble with speculation when trying to collect clothing. In 1862, General Lee and Bragg both realized that their requests for uniforms to the Confederate government were more likely to go unanswered than not. Confederate soldiers were all too often dressed in Northern uniforms they captured on the front. In what Arliskas refers to the middle war period, beginning in October of 1862, the Confederate Quartermaster accounted for every piece of uniforms, and the Quartermaster department became very strict in administering their duties. Soldiers complained that the government clothing was of poor quality. ${ }^{146}$ However, government clothing was not the only variety that soldiers found faults with. Many ladies were not experienced with clothing production, and their attempts to supply their husbands and other soldiers were not especially successful.

Not all women were adept at stitching for the soldiers. Some newspapers alluded to the failure of some stitching. In a section titled "A Hint for those who make Soldiers' Clothing," the article discusses a soldier letter that described the failures of handmade clothing, "Our pants, jackets and under clothing invariably rip, after a few week's service, into the original pieces. Then comes a little swearing and sweating, and a weeks darning and stitching, before we are fit to appear in public, unless we have lost all decency, and come out with a "flag of truce" flying in the rear." The soldier continues to say that he "would be glad if some of the women who do

\footnotetext{
${ }^{146}$ Arliskas, 18-21, 26, 41-43, 51,54.
} 
sewing for the soldiers would pay us a visit - I have not a doubt but that they would return with many good resolutions, and with the conviction that our clothing is "wonderfully" if not "fearfully" made. ${ }^{147}$ This article pokes fun at the ladies attempting to sew for their loved ones that did not have previous experience. Many of their products were not up to the standards newspapers promised homespun items would hold. Soldiers often had to redo the weak stitches women placed into their uniforms. This article detracts from the image of the effective and loving housewife waiting at home for her husband to return from the war serenely knitting him stockings and stitching his uniforms. If women were not able to make uniforms of better quality than a manufacturer, it makes the Southern women seem less like the traditional homespun Southern lady.

While papers compared the war to the American Revolution, ladies' contributions were also measured against those of revolutionary women. "The ladies of the Southern Confederacy are, perhaps, not aware that in knitting socks for the army they have the precedent of one of the loveliest women that ever graced high station — the beautiful wife of our own Washington." Nothing more seriously prompted women to knit than the example of Martha Washington. Newspapers made clear she was a woman Southern ladies should exemplify, especially with their stitching. Washington was called "cheerful" and agreeable," largely because of her feminine and patriotic habits. "She had been remarked for an inveterate habit of knitting. It had been acquired or at least fostered, in the wintry encampments of the Revolution, where she used to set an example for her lady visitors by diligently plying her needle, knitting stockings for the poor, destitute soldiers." 148 If women were not able to make successful and well done uniforms,

\footnotetext{
${ }^{147}$ The [Richmond] Daily Dispatch, March 23, 1864.
}

${ }^{148}$ Nashville Union and American, September 13, 1861. 
they lost their similarities with the revolutionary women who, according to public memory, stitched so successfully for revolutionary soldiers. ${ }^{149}$

Many states took it upon themselves to clothe their armies, with North Carolina being the most efficient and well stocked. Arliskas details the many struggles soldiers had with finding clothing from the government, particularly clothing suitable for winter. The ladies' societies, even struggling with scarcity, did their best to match soldiers' pleas, and were life-savers for many men in the army. In the final period of the war, beginning in November of 1864 , the Army of Northern Virginia was decently supplied ${ }^{150}$. The Richmond Enquirer asked women to "speedily knit socks for their relatives, and that every lady will feel herself especially called upon to aid in procuring socks for the army." 151 The paper later wrote that, "In nothing did he pride more than the toiling patriotism and spirit of self-sacrifice displayed by our women. They spin, and weave, and sew for the soldiers, while their eyes are dimmed with the tears of woe that have saddened almost every heart and desolated every heath in the land." ${ }^{152}$ This paper emphasized that the women of the South worked so hard, and went on to connect it to the sentimental nature of the textile exchange, "Those who have parental hearts know the emptions of the solder toward those who are mindful of him and the loves ones he has left behind." ${ }^{153}$ While this article does not directly mention the love lost between spouses, it may be applied to the wives and children left behind by soldiers, and the wives spending their time at home stitching uniforms for their husbands.

${ }^{149}$ Patricia West, (Domesticating History: The Political Origins of America's House Museums Washington, DC\& London: Smithsonian Institution Press, 1999) in her discussion of historic house museums, describes how the ladies association formed to protect Mount Vernon used Washington's home to strengthen national identity and their cause. Both North and South Appropriated George and Martha Washington in order to strengthen their rhetoric.

${ }^{150}$ Arlsikas, 60,90.

${ }^{151}$ Richmond Enquirer, November 13, 1863.

${ }^{152}$ The [Richmond] Daily Dispatch, December 13, 1862.

${ }^{153}$ The [Richmond] Daily Dispatch, December 13, 1862. 
The Bond family often exchanged textiles, and while at war Bond was especially appreciative of textiles his wife sent him, and he connected those gifts to the intense feelings he felt for his wife. Upon receiving a coat and stockings, he told Lizzie "You are the best wife in the world." And then he later wrote "I forgot when I was writing about my clothes to say anything about the [clothes] you sent me it is the best I ever saw." 154 Bond is clearly proud of his wife's' contribution to his uniform, but also appreciated her skill. While Bond was often sent items by other family members, and some items made by slaves, he is most complimentary regarding gifts from his wife. However, Bond often experienced difficulty in getting the clothing Lizzie sent for him. "You wrote about my clothing. [The clothing items] are at Manassas and Capt. Graves is making arrangement to send for them so I am in hopes I will get them yet ... give my thanks." 155 Bond often asked her to send him clothing, specifically pants for which he specified he wanted "heavy gray if you can get it an if not any kind, have them with something strong." ${ }^{156}$ Bond was very specific about what clothing and what other items his wife might send him that would make him the most comfortable. However, he attached both utilitarian and sentimental meaning to what he received.

When Bond wrote his wife that he was "the finest dressed man in the camp and the ladies fall in love with me everywhere I go," he was telling her how proud he was of her successful stitching. He felt affection from his wife when he received uniform items she prepared for him. However, within this exchange, Bond, a long time married man with children, fell into patterns reserved for courtship, like the gentle teasing following his thanks, "sometimes the boys pass me

\footnotetext{
154 The Bond Family Correspondence, No date.

${ }^{155}$ Henry Bond to Elizabeth Bond, November 25, 1862, Bond Family Correspondence, Virginia Historical Society.

${ }^{156}$ Henry Bond to Elizabeth Bond, September, 29, 1862, Bond Family Correspondence, Virginia Historical Society.
} 
off for a single man and have near fun." ${ }^{157}$ With that statement, meant to make his scolding wife at home fret over what that fun might entail, was sure to receive a vehement reply, but a reply that would likely be accompanied by carefully knit stockings. Love and sentiment were very essential pieces of the textile exchange that clothed so many men during the Civil War. However, not all marriages were as successful as the Bonds. Civil War couples had to deal with great scarcity, these pressures often led to marital difficulty. Of course, many couples did not survive the war at all. Widows especially had to navigate mourning in the Civil War.

\footnotetext{
${ }^{157}$ Henry Bond to Elizabeth Bond, January 1, 1862, Bond Family Correspondence, Virginia Historical Society.
} 


\section{Chapter 3: Deconstruction, Mourning, Scarcity and Divorce}

Judith McGuire wrote how it was "melancholy to see how many wear mourning... one sad girl sits near me...but she is too poor to buy mourning." 158 Southern civilians and soldiers alike often had to mourn the loss of a loved one during the war, but also had to deal with the great scarcity that occurred in the South. The nature of death and scarcity in the Civil War made it difficult for widows to mourn the loss of their loved one. McGuire touches of the problem of one woman who was unable to properly mourn for her loved ones because of a lack of mourning clothing. Problems with scarcity made it more difficult for women and solders to continue the great textile exchange as the war continued. Southern people believed textiles used to mourn loved ones were significant because they represented a proper way to grieve and remember their loved ones: soldiers and civilians alike saw the textiles used to mourn loved ones as emotionally important.

Mourning clothing, like veils, came to represent the great loss many women experienced during the war. While in North Georgia, a Mrs. Alexander Major wrote of a Confederate widow who saw her mourning textiles as especially representative of all she had lost in the war. Mrs. Stuart had a story similar to many other Confederate women, her husband died at Antietam and her young son perished as a drummer boy under Stonewall Jackson. The men in Mrs. Stuart's life had died in the Civil War, and experienced a death far different than the quiet death at home she imagined for them. Mrs. Stuart, however, was particularly bitter, "I hate [Yankees] and I never will forgive Abraham Lincoln for having brought on this terrible war that has not only

${ }^{158}$ Judith W. McGuire, Diary of a Southern Refugee During the War, by a Lady of Virginia, (Lincoln: University of Nebraska Press, 1995): January 3, 1865. 
beggared us financially, but has taken away our loved ones, and left us bankrupt in affections," and she continued to say" I wear black for my dead and I weep, but if anything happened to him I think I should shout for joy and be tempted to flaunt the gaudiest colors I could find." 159 Mrs. Stuart allowed her feelings on the possible death of Lincoln to be broadcasted throughout her community with textile imagery, which caused problems when Lincoln was assassinated. Mrs. Major described, "The stores were ransacked for black material to hang forth as symbols of mourning. Every house was ordered to be draped in black, and where the rebel inmates refused, it was done for them by the Union boys." 160

Mrs. Majors vehemence soon attracted the anger of Northern soldiers. A squad of Northern men organized themselves into an inspection committee and went from street to street to see that no house was left undraped. Presumably, the Union presence ordered the civilians to drape their homes in black to mourn for the President. The committee of Union soldiers charged with ensuring all of the homes were draped were angered by Mrs. Stuart's refusal to mourn the President. Even when Mrs. Major's husband went to the store to collect black mourning drapes, the soldiers were not appeased. Mrs. Stuart went on to make clear she blamed her current state on the President, and the entirety of the Union, "What, I show a sign of mourning for Abraham Lincoln—I, who but for him would not be husbandless and childless today!"161 The committee continued to search Mrs. Stuart's home, "I knew from the should of triumph that they had found something; but I was hardly prepared for the sight when a few minutes later they came rushing down the stairs waving with frantic gesticulations Mrs. Stuart's long crepe veil.” It is clear by the horror Mrs. Major expressed at the use of that veil to mourn Lincoln that she saw the veil as

${ }^{159}$ Walter Sullivan, The War the Women Lived: Female Voices from the Confederate South, (Nashville: J.S. Sanders, 1995).

160 Sullivan, 274.

${ }^{161}$ Sullivan, 274. 
representative of the grief she felt for her husband, "the veil that she had worn in double bereavement when her son had shed his young blood for his beloved South...Her life has been keenly embittered and her heart sorely bruised by this war." ${ }^{162}$ Mrs. Stuart was not alone: many other Southern widows also had difficulty accepting their fate after the war in which they lost their husbands. Instead of hanging the fabric for mourning, Mrs. Stuart, dressed completely in her mourning clothing, hung herself in full view of the Union soldiers. Mrs. Major wrote that with the "crepe veil floating out," on the rope hung "all that was mortal of that once proud Southern woman." ${ }^{163}$ Mrs. Major was unwilling to taint her mourning clothing by using it for Abraham Lincoln.

While this tale is tragic, it is also illustrative about how seriously Mrs. Stuart took the textiles she used to mourn her husband and son. Because of the war she lost her family, and while this is Mrs. Major's retelling, it seems that Mrs. Stuart felt displaced after she lost her life as a wife and mother. Mrs. Stuart used fabric to honor the death of her husband and her son. This act was clearly meaningful to her as well as the people around her. Her refusal to utilize mourning fabrics upon the death of Lincoln was an unsurpassable affront to the Union army. It is also notable that it was especially important to the soldiers that Mrs. Stuarts personal mourning possessions be used as opposed to fabric Mrs. Major's husband purchased at the store. The Union soldier recognized that some fabric was more meaningful than others: it was not just the black fabric that was necessary, but fabric that was embodied with meaning from the owner. ${ }^{164}$ Fabric was not significant on its own, but it became significant because of the meaning placed on it by the owner.

\footnotetext{
${ }^{162}$ Sullivan, 274-276.

${ }^{163}$ Sullivan, 276.

${ }^{164}$ Ibid., 274-6.
} 
Textiles and laboring over textiles were often a part of the mourning process. Beth Fowkes Tobin and Maureen Daly Goggin argue that the "sentimental labor" of women after a death exemplified their participation in social mourning customs. While death represented an end, "objects in outlasting the living can convey a sense of permanence in the face of loss." 165 Objects have the ability to serve as a permanent memory of the dead. "The material culture of death straddles the binaries of life and death, subject and object...rendering them unstable...turning objects into subjects and subjects into objects."166 Objects like memorial samplers were meant to help a widow deal with loss. Women, with sentimental labor, were essential in proper mourning, whether it involved stitching a sampler or wearing mourning clothing. Mrs. Stuart associated her veil with the memory of her lost husband.

Southern civilians had exacting rituals surrounding death, but the Civil War forced them to question those beliefs when the war made grieving rituals impossible to fulfill. Nineteenth century people were familiar with death. Drew Gilpin Faust argues Civil War civilians were forced to cobble together a new way of life that would help them cope with death. Like love, suffering in the Civil War was something no one understood, but was expected as a daily part of life. Confederate citizens would have been very familiar with suffering in the course of their lives, however, the Civil War changed suffering for soldiers and civilians alike. For soldiers, experiencing death on a battlefield forced them to question their preconceived notions, and for civilians their notions were questioned by their inability to be with their loved ones when they died. Before the war, suffering was measured and it contained lessons, like a person's meaningful last words. Civil War civilians and soldiers alike struggled to ascribe meaning to the

${ }^{165}$ Maureen Daly Goggin and Beth Fowkes Tobin, Women and the Material Culture of Death, (Routledge, 2013): 2 .

${ }^{166}$ Ibid., 2-3. 
suffering they dealt with in their daily lives. Dying violently on a battlefield or dying of disease at home was not a good death, and for many they were so far separated from their loved ones there was no time to find meaning. ${ }^{167}$

In the Civil War, for both the North and South, grieving was a ritual. If a loved one was dying, all of their family was supposed to gather around them and be there for a peaceful and brave death. Religion was closely involved, whether faith was reaffirmed or found. Last words and last moments were supposed to impart meaning on the victims' life. Consciousness and Christianity were important aspects of a good death. ${ }^{168}$ When soldiers did not die surrounded by loved ones, survivors had to question the meaning of their life and death. Civil War civilians and soldiers alike tried to create a good death for their fallen loved ones. An example would be from the song "Let me Kiss him for his mother," a tune that promised loved ones at home a kind nurse might be a substitute for a wife or mother in a soldiers final moments. Another song was written in answer "Bless the lips that kissed our Darling as he lay on his death bed, Far from home and mid close strangers, Blessings rest upon your head...Oh my darling, oh our dead one, though you died far, far away you had two kind lips to kiss you." ${ }^{169}$ Even though women might not be with their husbands when they died, they could believe their husbands had a "good" death thanks to other women acting in their stead.

Unfortunately for women at home, it was often the case they were not able to receive confirmation their loved ones had been given a good death. Wives wanted to be able to view the bodies of their husbands and give them a proper burial. While this was part of a good death, it also prevented fantastical hopes that their husbands might still be alive. Misidentification was a

\footnotetext{
${ }^{167}$ Faust

${ }^{168}$ Faust, 9, 11, 17, 22.

${ }^{169}$ Faust, 12.
} 
possibility in the minds of many women who heard their husbands had passed. This was also important for more practical matters: in order for widows to settle legal matters a place and date of death were often necessary. Also, women felt they needed the correct information so they might properly mourn their husbands. It was said of many women that they died of grief following the death of their husbands. However, many soldiers at war had to worry about the death of their wives as well. Civilians might die from accidental war deaths, disease, and starvation." 170

While Southerner's might have been familiar with death and infant mortality, they grieved very deeply and utilized various mourning rituals to overcome their grief. Craig Thompson Friend, in an essay about Southern parents mourning a child, emphasizes that enslaved people were part of most major events in a white plantation families' life, from birth, to marriage, and even scenes of death. This brings up notions of a "good death," enslaved people were often on the scene as a white family member died. In the language of death, there was a focus on leaving earth in order to find long dead relatives in heaven. ${ }^{171}$

For war widows, their future without their husbands often looked very bleak. Newspapers were often populated with tales of the woes that befell widows. A letter from the Stonewall Brigade to the Staunton Spectator, depicted one war widows struggle. According to the letter, at the battle of Paynes Farm, "one of the best and bravest soldiers...fell mortally wounded whilst charging the enemy" the paper continues to describe how "his admiring and sympathizing comrades out of their own small means made up money enough to have the body taken from the battlefield and sent to Augusta County for burial, that their gallant comrade might rest beneath

\footnotetext{
${ }^{170}$ Faust, 118, 130, 139-142.

${ }^{171}$ Craig Thompson Friend and Lorri Glover, Death and the American South, (Cambridge University Press, 2015): 65-66.
} 
the soil that he had so long defended so bravely and loved so well." 172 Even with the help of her husbands loved ones, the widow continued to struggle. "The distressed widow of the deceased soldier, on the arrival of the body at home, took the twenty dollars which is allowed by the county to the wives of soldiers for their support, and wishing to pay the last sad rights to her husband in the usual manner, went to a prominent cabinet maker in Greenville for a coffin." Unfortunately, the coffin maker charged the widow forty dollars. The soldiers collected the rest of the funds, and then wrote the paper again to threaten the coffin seller, promising that though they were more "accustomed to handling the musket than the pen" the wanted to let the citizens of the county know the unfair practices of Southern merchants made them no better than men from "Yankee land." 173 By comparing Southern speculators to Union merchants, the article makes clear the negative opinion of speculators. This article indicates some of the troubles a war widow might have immediately faced after the death of her husband. This reflects the struggles with scarcity civilians dealt with during the war. Southern Soldiers worried speculators would rid their wives of their funds for necessities. This widow had to spend the entire means of support she was given by her county to purchase a coffin for her husband. This burial was expensive, from the transport of the body to her husband's final resting place. However, the widow and the soldiers clearly felt it necessary for this man to have a good and honorable death.

Following the loss of a loved one, women were expected to do the job of mourning through textiles. Mourning was gendered in the Confederacy. When women mourned, they wore mourning for two and one half years, but when their husbands mourned, they wore an armband for three months. ${ }^{174}$ Largely, women were tasked with the work of mourning in the Confederacy.

172 Staunton Spectator, March 29, 1864.

173 Staunton Spectator, March 29, 1864.

${ }^{174}$ Faust, 148. 
It was their duty to prepare their homes for mourning when there was a death as well. There were three stages of mourning for women. The first included all black and drab fabrics that emphasized simplicity with a veil. The second stage was still black, but lace and other adornments were allowed. In the final state, bonnets were allowed, as were gray and lavender for color. When women mourned, they were supposed to spend their time with memorial activities, of which stitching was one, particularly stitched pictures embroidered with silk. ${ }^{175}$

Upon a death, women had many options for objects to mourn their loved ones, however, samplers allowed women to labor over an object in their grief, and memorialize their loved one. Mourning, and how to mourn, was very much shaped by class. Elite and middle class women would be able to do fancy work, more elaborate needlework with finer materials, while lower class women would do plain work do to their lack of time and funds. While mourning samplers began to lose popularity in the United States in 1850, they exemplify how labor over textiles might represent mourning. Young antebellum women were often asked to stitch mourning samplers: it was a part of their education that improved their sewing skills but also taught them about the connection between textiles and mourning. Maureen Daly Goggin argues "this sexist view of women was woven into the cultural fabric in which both men and women participated." ${ }^{176}$ Mourning was gendered, and so were the textiles surrounding mourning.

As the Civil War continued, more Southern civilians were touched in some way by death. For women who lost their husbands, they might choose to remarry and stop wearing their mourning clothing and join society, or they might continue wearing mourning and dedicate themselves to preserving the memory of their gallant loved ones. However, if their husband

${ }^{175}$ Dorothy Denneen Volo and James M. Volo, Daily Life in Civil War America, (Westport, Conn: Greenwood Press, 1998),:289, 294.

${ }^{176}$ Goggin, 66, 76, 93. 
survived the war, it was still the duty of the wife for mourn for loved ones lost in the midst of the conflict. While men continued to fight the war, women at home did their best to honor the memory of those who had already died. When Stonewall Jackson died, for years to come women dressed in black visited his grave to honor the general. ${ }^{177}$

The Civil War cut many marriages short, but even in short marriages textiles played a role. One of the most often told tales of mourning would be the story of Hetty Cary and her illfated wedding. Constance Cary Harrison recalled "the nuptials of one called by many the most beautiful woman in the South, with a son of Richmond universally honored and beloved." Cary Harrison described a "strange series of ominous happenings" that occurred before the wedding, for the superstitious a predictor of the married couples' fate. Cary Harrison described how Hetty had visited her, "bringing her bridal veil that I, with our mothers, might be the first to see it tried on her lovely crown of auburn hair." However, while trying on this important textile keepsake of her soon to be wedding, "the mirror fell and was broken into small fragments." ${ }^{178}$ While not all of the happenings described by Cary Harrison involved textiles, many did, such as the dropping of a lace handkerchief and the ripping of the beautiful veil. ${ }^{179}$ Cary Harrison seemed to look back at the incidents surround the veil as foreshadowing a short time later when Hetty Cary would be forced to wear a veil of mourning. Only three weeks following the wedding of Hetty Cary to General John Pegram, Pegram was awoken with news of battle. Cary Pegram spent the day with her mother "carding lint," a war time aspect of textile production, however it was then, according to Cary Harrison and her recollections, Hettys husband was killed. Only three weeks after marrying her husband in a tulle veil, she would be wearing unadorned black and beginning her

\footnotetext{
177 Women in Mourning: a Catalog of the Museum of the Confederacy's Corollary Exhibition Held November 14, 1984 through January 6, 1986, Richmond, Virginia, 8.

${ }^{178}$ Cary Harrison, 149.

${ }^{179}$ Cary Harrison 149.
} 
mourning period. Cary Harrison recalled her cousin "was like a flower broken in the stalk," and such was grief in the Civil War. ${ }^{180}$

Mourning women would have been a familiar sight in the South in the years following the war. The Staunton Spectator, in a section titled "She Goeth unto the Grave to weep there," a writer described following a woman in deep mourning travelling to a cemetery. The writer's friend, also watching the woman, remarked, "Perhaps it was the grave of her husband, the loved sharer of former joys, the tender parent of her sons and daughters yet spared to her...Since there are special promises to the widow and orphan, whereby they have peculiar claims upon God for his care and guidance in the varied scenes of a widowed and forlorn life." 181 The author admits that the life of a widow was particularly "forlorn." Following the war, it was common for newspapers to follow the preservation of the cemeteries for deceased Confederate soldiers. The Richmond Daily Dispatch characterized one widows visits, "There was the pale faced lady, dressed in deepest mourning, wiping away the tears that blinded her, that she might, with tender care, brush the dust from the spot where lay he who, after a few brief months of happiness, had died at Chancellorsville." 182

Textile objects were often used by widows to mourn their husbands, whether it was the mourning clothing they might choose to wear, or the battle flag made from bridal clothing their husbands died under. On July 29, 1875, The Anderson Intelligencer provided its readers with in depth coverage of a reunion of Orr's Regiment of Rifles, a reunion at Walhalla, South Carolina at which the silk battle flag played a key role. The paper described the men, still strong after ten years, marching with a flag that had been made by women in Charleston at the start of the

\footnotetext{
${ }^{180}$ Cary Harrison, 151.

181 Staunton Spectator, November 26, 1867,

182 The [Richmond] Daily Dispatch, May 11, 1866.
} 
conflict. Later in the article, the reader learns that the fabric that was patriotically used to stitch the Palmetto tree that was the main feature of the flag came from the "bridal dresses of the wife of one who was distinguished in the Confederacy." ${ }^{183}$ It was the bridal dress of the wife of General Ellison Capers. The flag that was carried ten years after the war was not simply ceremonial, and it was not one of the many silk flags deemed inappropriate for practical use and sent home at the start of the war. The flag was used at many battles, the paper specifying its presence at Manassas, Sharpsburg, and Cold Harbor. The meaning of this flag was not only relevant to the woman whose bridal clothing was donated or her husband, but also to the wives of the men who died fighting under the flag. Following the war, the flag was given to a Mrs. Marshall, who brought it for the ceremony. She had presented the unit another flag and kept the original because she had "desired to keep the flag under which her gallant husband fell." 184 Speeches from the day of the ceremony argued that Southern soldiers who deserved honors were forced to suffer. "The forlorn, uncared-for condition of the poor confederate soldier should only bind us closer together, it reflects back and gives an increased interest and sadness to the great struggle in which they followed their honest convictions, and fought with heroism and fell without dishonor. My comrades, if our services in that war deprive us of all else, we have left to us, at least the consciousness of rectitude and the pure pleasure of such reunion as this." 185 The reunion, and the flag the men could still carry, signified the romance of the Confederate cause, but also spousal devotion. This was not the only flag that was honored and utilized for mourning loved ones years after the wars end.

\footnotetext{
183 "Reunion of Orr's Regiment of Rifles," The Anderson Intelligencer, July 29, 1875.

184 Ibid., July 29, 1875.

185 Ibid., July 29, 1875.
} 
Ideals of proper mourning were constantly changing in the South, and became original in the Civil War. As Martha Washington was a role model for Southern women in textile production, she was also a role model for mourning, as was Varina Davis. According to Meredith Eliassen, Martha Washington set many customs of mourning for the United States when she mourned for her husband. She was sent tokens of mourning from people throughout the country, many in thread, and responded to each. The market was flooded with cheaply produced mourning materials to mourn Washington. However, Martha Washington was seen as the example, of how women should mourn in their new country. In the nineteenth century, people feared a life where their death was not heavily mourned. It was the job of those left on earth to mourn their loved ones heavily to indicate they were well loved. Varina Davis also served as an example for proper mourning during the Civil War. The American Civil War Museum holds a half mourning dress that was made from fabric from a sale supposed to benefit the Confederate Soldiers home. Mourning was connected to the Civil War even twenty years following. ${ }^{186}$ Of the many items of mourning clothing held by the museum of the Confederacy, some of the most notable belonged to Varina Davis, who mourned for her young son that died in an accident in the midst of war. While Jefferson Davis mourned his son, the work of mourning was done primarily by Varina Davis. While in half mourning, Davis wore a dress made of purple cotton and black decorations. The dress had buttons on the front, and a long cotton fringe, a fringe that was allowed because of her half mourning status. It also included white tape decorations. This dress was made in 1864. Particularly notable about this dress was the allowance in the front, for Varina Davis would have worn the dress while she was pregnant. Mourning dresses were meant to be plainer than those Southern women typically wore, but this

${ }^{186}$ Women in Mourning: a Catalog of the Museum of the Confederacy's Corollary Exhibition Held November 14, 1984 through January 6, 1986, Richmond, Virginia, 8. 
dress also suffered from lack of funds and materials. At a cost of one thousand Confederate dollars the price was already high for the Confederate first lady struggling with scarcity. Of course, Davis' struggles were far less than many Southern women without her resources. Davis was tasked with mourning her son, and she could not do so as she would have before the war due to wartime scarcity. She was also in the second stage of mourning during her pregnancy, an important life event and event in her marriage in which she had to continue mourning her lost son. Mourning and scarcity went hand in hand during the war. ${ }^{187}$

Women throughout the South struggled with the textile scarcity. Constance Cary Harrison wrote after the war of how ladies were starved for textile products during the Civil War due to the blockade. While writing of her quest to receive some French lace, she described other women and their quest for goods, "We even heard of a private in the Confederate ranks bringing back from Maryland a pair of stays, which he presented to his fiancée.” Cary Harrison remembered that she was able to procure a pair of boots from one officer when he was no longer able to get them to their intended in New Orleans. However, the ability to procure items, textile fashion items in particular, was a great feat sure to impress women in the Confederacy who were accustomed to finer fashions and fabrics. The man who was able to procure stays for his fiancée was seen as a romantic figure, one notable enough for Cary Harrison to remember after the war. This was the way blockade runners made a great deal of profit, as Cary Harrison continued to write, "A blockade-runner, coming in to a Southern port, brought, instead of arms and drugs, an entire cargo of corsets sold out at great profit by the venturer who had stocked her! For women must lace, while men will fight, might have been a motto of the hour!" 188 Regardless of the truth

187 Ibid., 8 .

${ }^{188}$ Nathaniel Cheairs Jr. Highs and S. Kittrell Rushing ed. Refugitta Of Richmond: The Wartime Recollections, Grave and Gay, Of Constance Cary Harrison, (Knoxville, Tennessee: University Tennessee Press, 2011): 91 
in this statement, this selection once again illustrates the pervasiveness and importance of fashion and textile items in Southern culture, but it also romanticizes the practice of procuring fabric items from the blockade for a loved one.

Southern women had to be creative in order to keep themselves in textiles during the war. Cary Harrison wrote "hope springs eternal" to describe how she prepared for an evening function which previously she would have procured new and fashionable clothing for, "Two venerable dresses in the family repertory, a fawn and a brown silk, were ripped, pressed, laid upon patterns of the latest date, per underground, and trimmed with double-pinked quillings of the same materials...We had invented, pinked, ruffled, and sewed ourselves into a state of exhaustion, when at ten o'clock at night the last stitch was set, and I soon stood arrayed in what at casual glance seemed a brand-new modish toilette." Cary Harrison was looked upon with envy because of her ability to create clothing in the times of scarcity. Of course, Cary Harrison had an advantage due to her elite status. She knew she was successful in her efforts when she heard "other girls whisper that I had got another new dress by blockade. But I took care, during the evening, to sit in sequestered spots, not daring to stand anywhere near the central chandeliers." However, Cary Harrison's work was revealed when other ladies asked to see the dress so they could copy the pattern, "Full well I knew that in daylight all the pressed places, pieced places, washed and ironed quillings, the age and expedients of that pre-sumptuous garment would stand revealed! But I bravely lent it, and the poor dear fraud came back within the stipulated time." 189 Even in the midst of war when textile items and fashions were difficult to find elite Southern women worked to improve their wardrobes. This was all part of the Southern system, which was intrinsically tied to courtship and marriage. Women felt they had to look attract in order to attract

${ }^{189}$ Cary Harrison, 100. 
soldier husbands. When women were unable to procure new textiles, it challenged the fabric of Southern society.

Harold Wilson, studying the Confederate Quartermaster, argues that the greatest problem for the quartermaster was scarcity of textile making production. Wilson argues that the South was only behind European countries and the North in wool production and spindles, but "While the Confederacy mobilized these resources, the Union Systematically endeavored to destroy them." ${ }^{190}$ However, the greatest problem for the South was a lack of sheep. Due to this struggle, the Confederate army and Southern civilians struggled greatly to endure the war. However, Wilson questions why this was the case. At the time of the war it is estimated the South had at least 250 cotton mills. Wilson, relying on the previous work of the Joseph C. G. Kennedy 1860 census, wrote that while there were 153 factories in the South that produced nine million yards of woolen goods in 1860, half of these were in the border states. However, of the 153, Virginia held forty-five producing one million yards of goods. ${ }^{191}$ However, very early in the war manufacturers began struggling to find parts for their machinery, especially when men realized the ports would soon close. However, things like dyes and cotton cards became difficult to find quickly. When the Crenshaw Woolen Mill was able to get logwood, a purple-black dye, through the blockade, companies throughout the South were relieved. When manufactures failed, even the manufacturers called for women to become involved in clothing production, particularly with stockings because industry was especially bereft when it came to equipment for manufacturing socks. ${ }^{192}$

${ }^{190}$ Harold S. Wilson, Confederate Industry: Manufacturers and Quartermasters in the Civil War, (Jackson: University Press of Mississippi, 2002): Vii.

${ }^{191}$ Wilson, xvi.

192 Wilson, 15-16, 25, 
While the Confederacy was seemingly capable of proficiently clothing itself, it did not during the war. Wilson writes that there should have been a sufficient number of sheep in the Confederacy to clothe the army. However, the wool supply decreased quickly. Each soldier required approximately 16 pounds of wool, yet the wool was disposed of for other purposes. ${ }^{193} \mathrm{~A}$ great deal of wool was held in Texas. Many sheep were slaughtered during the war for food, and then some were held by Unionists, still resisting the Confederate government. The price of yarn rose from $\$ 1$ to $\$ 5$ for a standard skein. There was also great deal of anti-manufacturing sentiment in the Confederacy. Eventually, the Confederate Government took a great deal of regulatory authority within the textile manufacturing industries. Price controls were set in an attempt to affordably clothe the Confederate army. Then there came the problem of quality. Many soldiers complained that their manufactured goods were of too poor a quality to be useful. ${ }^{194}$

An especially difficult item to procure was card clothing. Hand cards were in demand as planters revived the use of old loom rooms for the duration of the war. In September 1862, Francis Fries noted with pleasure that the brother of a prominent Columbia hardware merchant, an old friend, had "gone into the manufacture of cards \& has fair prospects of success." He was delighted because "this Confederacy has been woefully deficient in men that are willing to invest their means in enterprises of this kind \& we now see the evil of it.' '.. Production was limited because cards could be manufactured only on special machinery and required large quantities of wire and leather. ${ }^{195}$ As the war went on, the South began to import spinning, weaving and sock making equipment. However, who was making the garments changed. More

\footnotetext{
193 Wilson, 28.

194 Wilson, 66.

195 Wilson, 132.
} 
women and children began working in manufactures to supply the South. This lifestyle was not safe and the hours were long and tedious, but the Confederate army was supplied. Some items most needed by the Confederacy included various oils to lubricate the cotton equipment. ${ }^{196}$

For many, frivolity was a problem in society, because many commented that people should not be frivolous because of all of the wartime scarcity. The Richmond Enquirer often wrote of the desperate need for socks in the army, "there is a great scarcity of socks in the army of Northern Virginia. - Gen Lee has lately, we are advised called upon the ladies of Richmond to aid him in procuring socks for his army." The paper went as far as to invoke the name of General Lee, and then wrote who they believed should be responsible for procuring the socks, "We hope that the mothers, sisters, and aunts of the gallant soldiers will speedily knit socks for their relatives, and that every lady will feel herself especially called upon to aid in procuring socks for the army." Finally, the paper addressed the fact that not only was the Army of Northern Virginia lacking of socks, the entirety of the South was lacking wool and other yarns, "There is, we know, great difficult in purchasing yarns, but where yarn cannot be procured, cotton is better than nothing. Let the ladies of Richmond meet together and take this important matter under their charge. Let all "club dancing parties" cease, and knitting parties meet to ply the needles for the benefit of the soldiers." ${ }^{197}$ Like other articles, this was not kind to the women in the South struggling to make ends meet, but instead blaming frivolous feminine behavior as the root problem for the scarcity. According to this article, every time a woman danced, they were wasting time that was supposed to be spent working for the soldiers.

Newspapers often published examples of good work done by ladies in order to praise the individuals, but also to set examples for other women. The following is one example, "Mrs.

\footnotetext{
196 Wilson, 150-153, 200.

197 Richmond Enquirer, November 13, 1863.
} 
Summons, a widow lady of this county, has made during the present year 300 bushels of corn, 100 bushels of potatoes...enough to fatten her hogs. She did all the plowing and did it with an old windborne pony. Her two little daughters, aged 10 and 12 years, did the hoeing. She has also made 100 pounds of tobacco, now in press." This Mrs. Summons did not only produce enough crops to support and feed herself, but she had also successfully produced her own textiles, "Since her crop was diminished she has done weaving enough to buy her salt. And a pair of cards and has some money left. Please give this an insertion for the benefit of widows and soldiers' wives, who are depended on the cold charity of state aid for assistance. There are hundred scattered over the country, who, by a little more industry, could make their own support and live independently. ${ }^{198}$ While this article is supposed to praise one exemplary woman, what it really does is inform other soldiers wives what they should be doing, and how if they were starving, it was no one's fault but their own. In the Civil War, it is clear that being a good wife or a successful lady meant winning an unspoken competition among the other ladies of the Confederacy. The expectations for ladies changed drastically in the Civil War, from being polite and talented to being able to support oneself and ones household. Mrs. Summons was clearly very successful at the task, and was able to support not only herself but those around her because she found the means to do so. This article basically charges with widows and soldiers wives relying on the state at feminine failures. The paper claims that "by a little industry" women would not need the help of the state. Starving is unladylike, because true ladies, according to this paper, would be more industrious.

Southern newspapers often commented upon the scarcity in the Confederacy, including advice for how scarcity might be dealt with. Husbands fighting in the war were not called upon

${ }^{198}$ The [Richmond] Daily Dispatch, November 30, 1863. 
often to do more to end the scarcity plaguing the South, but wives were. Advice ranged from supportive and complimentary to harsh and accusatory for civilians. Newspaper articles often made it seem as if it was the fault of those at home that scarcity was a major issue, "October is here. It is not money that is called for particular in this case. Lincoln's ships by their blockade keep out the old supplies of flannels and cloth, and our manufacturing establishments are too limited yet to supply, at once, the vast demand which has been filled from the North heretofore." In this selection, the Staunton Spectator made it obvious that very early in the war the South struggled to create the textiles needed to survive and fight the war. The blame is very clearly laid upon the blockade. This selection clearly states the facts the Southern manufactures had to endure, "It is wool we want—wool spun and knit into socks, and wove into blankets and flannel. Have the looms gone to pieces? - make new ones. The time is ample if we commence right away, and if each lady will do her part to work up the wool." 199 This article makes it clear that if the ladies of the South stopped complaining about shortages and their struggles and instead began to fix their problems, like their broken looms. The newspaper even claimed that there was plenty of time to supply the South before the beginning of winter. In short, the South is struggling but would have no reason to if women were called to action.

For women who were already spinning and knitting, the newspapers were more complimentary. In fact, newspapers made work to overcome scarcity an extremely feminine activity, "The spinning wheel is to supplant the piano, and the dainty fingers that can fly so gracefully over the ivory keys will now play the whirling wheel—Stocking-yarn is in demand, and those who cannot spin can knit." The paper then alludes to how attractive and talented the young ladies of the South were, "It is said that "lilies do not spin, neither do they weave," yet our

\footnotetext{
199 Staunton Spectator, September 24, 1861.
} 
lovely "lilies of the valley," while they do not "weave," both spin and knit." ${ }^{200}$ The feminine grace that suddenly surrounded many textiles manufactures that were limited to slaves or women of lower classes feminized war work, and the grand contribution many Southern women made to the war effort. This attractiveness of spinning and knitting reinforces the ideal that fighting scarcity was attractive, and an activity any husband would be proud of. More accurately, it was an activity that bachelor soldiers would look on favorably. This was quite a change from the fashion fueled antebellum elite society.

Newspapers and soldiers blamed hardship on the merchants and the speculators who were selling goods to the government for exorbitant prices. This poem is telling, "I says the merchant, I bring the spun cotton, in fifty long years, I shall not be forgotten...I sell to the volunteer's wives and they weave it; And I let them have it for cash or for barter, And every few days I add on a new quarter..."201 This poem illustrates how a merchant might use textiles, like calico and muslin, to make a fortune. This poem is supposed to describe the many inappropriate habits of merchants and speculators, like hiding their items until their prices went up. The poem mocks the so called "kindness" of the merchant, as the man is tricking not only the soldiers' wives, but also their husbands fighting the war. In this poem, yet another one of a husbands' fears for his wife while he is fighting the war is realized. "My calico, muslin —in fact all my trinkets...I wish I had saved more domestic drillings...My old...calico is up to nine shillings!...I am a true patriot; all may suppose it." ${ }^{202}$ Husbands often sent their wives business advice when writing letters, and they worried that without their influence their wives might be swindled by other males.

\footnotetext{
200 The[Richmond] Daily Dispatch, September 13, 1861.

${ }^{201}$ The Abingdon Virginian, March 6, 1863.

${ }^{202}$ Ibid., March 6, 1863.
} 
Newspapers made it clear that scarcity was a problem in the South, among the wives and ladies at home and the soldiers in the army. The Quartermaster worked hard during the War in order to supply the South, as illustrated by this government sale of woolen scraps, "Suitable for carpet rags, and soldiers gloves... In Richmond, many persons have realized handsomely by picking up such scraps and selling the wool for spinning, weaving \&c. They will be sold by the pound. R. H. Phillips Asst. Quartermaster. ${ }^{203}$ While this might be a normal sale, the people of the South were desperate for the woolen scraps the Quartermaster provided.

Women working hard to end scarcity, and those who did not rely on the help of others, were praised. Newspapers were occasionally encouraging in their articles. However, less so for those dealing the with poverty the Civil War wrought, "Let not the good people among us once made rich by thrift and good management, but since made poor by the war, feel that they have lost in caste by the loss of wealth; the continuance of the esteem and respect of their friends will take from their loss half its pain." The article continued to discuss how the South should treat its newly poor citizens, "Let nothing be said or done to make any worthy Southern man, woman, or child feel ashamed of poverty. It is now more than ever incumbent upon those few who have the means of procuring luxuries, to refrain from ostentation and extravagance, out of deference to the feelings of their less fortunate neighbors." It is interesting to note that the paper does not recommend charitable giving, or other aid, but simply advises to refrain from grand displays of wealth while others do without, "A new social era now to be inaugurated where society can be enjoyed in homespun and calico, free form any hankerings after imported luxuries of the table, the ménage or the wardrobe. Some of these privatizations are found not a little annoying, more especially to those once used to abundance; but a little patience, aided by a little just and proper

${ }^{203}$ Staunton Spectator, January 211862. 
pride, will enable them to endure the change without murmur." ${ }^{204}$ This paper overstates the poverty and problems that many soldiers' wives endured in the midst of the Civil War. Calling the struggles to find clothing as well as food for soldiers' wives and men in the army "not a little annoying," still sounds like a gross understatement. Southern newspapers seem to refuse to acknowledge the grand suffering endured following the Civil War.

Cary Harrison described the dress of Southern women during the war stating, "Wonderful were the toilettes concocted that festal winter. Maternal party dresses that had done duty at Newport, Saratoga, Sharon, the White Sulphur Springs, and in Washington and New Orleans ball-rooms, were al-ready worn to rags" Cary Harrison here emphasizes that the beautiful clothing Southern women wore were not made in the South and therefore not available in the midst of the war. However, women continued to make due, "The oft-told stories of damask curtains taken down to fabricate into court trains over petticoats of window curtain lace, and of mosquito nettings made up over pink or blue cambric slips, now took shape. Certain it is that girls never looked prettier or danced with more perfect grace than those shut-in war maidens, trying to obey the great general's behest and look their prettiest for the gallant survivors of his legions." ${ }^{205}$ With this recollection, Constance Cary Harrison emphasized that the work elite Southern women did to improve their appearance was tied to their wish to find gallant soldier husbands, because hand in hand with the desire to look "their prettiest" for the soldiers was the ideal that their husband was a soldiers, and they did their duty to their husband by remaining attractive for him, but also they might find a soldier husband who could be proud of their appearance and form a Southern household.

\footnotetext{
204 “Merit Should be Standard", Staunton Spectator, October 23, 1866.

${ }^{205}$ Cary Harrison, 103
} 
Some creative uses for textiles, like smuggling or hiding previous items or funds, illustrated dangerous conditions and want in the Civil War. "I slept with the papers under my head Sunday night, and spent Monday afternoon in ripping apart the trimming of my gray beige skirt. You know that trimming, like...brown silk all around the hem?" Cary Harrison describes how she kept her papers safe during the war. While she originally had to sleep with the items under her pillow, she was able to protect them by ripping up her textiles and repurposing them. Cary Harrison continued to describe how she altered her dress to fit her wartime needs, "Well, into this wall of Troy I sewed with the tightest stitches I could make (you would say those were nothing to boast of, remembering the sleeve that came apart) every one of your precious documents. And here I am with the family fortune stitched into my frock, which I have determined to wear every day with a change of white bodices, till I see you or can get to some place where it is safe to take it off. .... I have certainly never since worn a gown of the value of that one, ungratefully cast aside at the first opportunity." ${ }^{206}$ This episode indicated how textiles were used in the desperate times of the civil war.

If both parts of a couple survived the war, they still struggled with the increased pressure the Civil War placed on marriages. Nikki Burg Burin, in an essay on one specific Civil War marriage, studies an antebellum couple in the South. Richard and Ann Archer had children, and a general successful marriage, but experienced multiple marital difficulties, difficulties Burin attributes to the couples many separations due to fiscal issues. ${ }^{207}$ While this was not a Civil War couple, their struggles illustrate the hardship married couples were forced to deal with because of the long term and forced separation the war caused in many marriages. Some marriages struggled handling the strain. In the midst of the Civil War, couples not only dealt with fear of

\footnotetext{
${ }^{206}$ Cary Harrison, 157.

${ }^{207}$ Burin, Sullivan, 134.
} 
death on the battlefield or at home, but also intense economic struggles, scarcity, and separation. Due to this difficult marital situation, many war time marriages struggled, and some couples divorced. The Columbia South Carolina Daily Phoenix wrote "There are said to be seventy-four divorce cases awaiting trial at LaCrosse, Wisconsin. Every complainant is said to be a soldier or a soldier's wife." 208 Southern Newspapers often wrote of how easy it was to procure a divorce in the Southern states. The Washington D.C. paper, Evening Star, wrote, "the frightful ease with which the wedding yoke is shuffled off 'out West," might be illustrated by a couple "who after living together without an unkind word passed for fifty years, were horrified on reading the morning paper to find themselves, by some mistake or practical joke, solemnly divorced by act of the state legislator. It is related that the worthy old couple wept on separate pillows that night." 209 This satire illustrated the feelings of the ease surrounding divorce. The couple renewed their vows and moved to a state where divorce was less prominent. The paper goes on to blame the war and greedy women for the rise in divorce, stating "many hasty marriages were contracted by soldiers; the motive being on the woman's part, to get a share...if the husband should be killed."210 The Richmond Daily Dispatch wrote of one Confederate soldier who obtained a divorce. James Simpson divorced Roberta Simpson because she committed adultery by marring a Joseph Cozzino in 1862. Roberta Simpson "charged that in the spring of 1861 the complainant willfully deserted her: leaving her without the means of support, and she has since learned he went into the lines of the Confederate Army." While he sent her a letter at Manassas she did not hear from him again so married another man for her support. However, even though when she learned Simpson was alive she returned to him and "believed he full intended to take her back as

\footnotetext{
208 The Daily Phoenix, August 29, 1865.

${ }^{209}$ Evening Star, August 05, 1868.

${ }^{210}$ Evening Star, August 05, 1868.
} 
his lawful wife," the divorce took place. ${ }^{211}$ Roberta Simpson had to deal with the scarcity of war with no support from her husband, and chose to marry again to support herself, thus bringing an end to her first marriage. This illustrates the trials married women faced during the war. Roberta Simpson likely mourned her first husband because she believed he was dead, but based on this limited article was forced to marry again to support herself.

The idea of divorce was gendered, as the newspapers were far more likely to blame the wife than the husband. The Morristown Gazette wrote, "This is a Tennessee romance: Husband leaves home in 1864 to find work. While at Atlanta hears that his wife and children are dead. He marries and acquires property. She hears of his whereabouts and enters an action for divorce and alimony. He faints with horror on learning of the complication. Second wife dies opportunely od consumption. Husband re-marries first wife." 212 This story is similar to the Simpson divorce, yet the husband is given no fault. However, these divorce proceedings indicate that marriages did struggle during the Civil War. In one case, a woman was attempting to marry, but then the 'Recorder' heard that the woman had "been married some four years since to a soldier, by the fellow had gone off a week or two after the marriage ceremony. Nothing had been heard of him since." ${ }^{213}$ This indicates the difficulties soldiers' wives faced, and the ambiguity of some marriages. The couples mentioned illustrate anecdotal evidence of struggles and confusion due to marital separation during the war due to scarcity or soldiering. Wives struggled to survive without their husbands, and husbands often had to leave if not for the army, to find work. The Civil War placed a great deal of stress on marriage.

${ }^{211}$ The [Richmond] Daily Dispatch, September 15, 1866.

${ }^{212}$ The Morristown Gazette, September 19, 1877.

${ }^{213}$ The Wheeling Daily Intelligencer, January 18, 1869. 
Some newspapers commented on the tragedy of the war, and described them through garments. The Staunton Spectator, in a section titled "A Sketch of Life," wrote about a sick soldier who deserted because his wife and children were starving, and compares him to a wealthy man who did not fight in the war:

"Come with me poor, wayward soldier, with your tattered garments... Who is this man that can revel in luxury and riotous living, while everyone else is mourning in sack-cloth and ashes on account of the great calamity which is now resting upon and devouring us. From whence all this luxury and grandeur? Go ask the poor widow and orphan children of him who poured out his heart's blood in defense of his country. They will tell you who it was, in the beginning of this war that made loud professions of patriotism and persuaded their husbands and fathers to go forth and do battle for their country while he remained at home and wrung the last morsel of bread from them that he might "dress in purple and fine linen, and fare sumptuously every day...."214

This "Sketch of Life," illustrates the unfairness of punishments for desertions. This short story describes men who did not fight in the war, but instead remained at home and profited from it. Many women and children suffered during the war because of the loss of their provider to the war effort and sky rocketing prices. This solder, in "tattered garments," left the war and was killed in an unhonourable manner, while the man extorting the widow for his wealth was allowed to live in luxury. The woman would now be forced to mourn her husband any way she could afford, and continue to struggle to feed her family. Women were expected to mourn, and do so to the full extent they could manage. Widows were given little sympathy when trying to feed their families. Thanks to the profit the man living in luxury made off of the poor widow, he was able to dress in fine and purple textiles. The article finished by stating, "Let us bring these two characters face to face that we may compare them for a moment. The one served his country until the sickness of his family required his presence, when he left in order to rescue them from

214 “A Sketch of Life, ” Staunton Spectator, March 29, 1864. 
starvation, for which he was tied to a stake and shot to death." 215 The short stories questions which man was more honorable. The tattered clothing of the soldier was portrayed as a credit to his honor.

The above tale tells of the struggles of both mourning as well as scarcity within the Civil War. People were touched by death in the Civil War, but procuring the textiles necessary to properly mourn, or even clothe themselves in the Antebellum style became difficult if not impossible due to scarcity. While soldiers and the Confederate government asked women to supply soldiers with their necessities, women at home struggled with scarcity of food, labor, and textiles. As the war continued more women struggled to supply their husband and their home with their textiles needs. This lack of textile necessities slowly began unraveling the fabric of Southern society, especially as textiles were a great part of the mourning process. Women used textiles as part of their mourning process to commemorate their loved ones, but also had to deal with problems of scarcity as the war continued.

${ }^{215}$ Ibid., March 29, 1864. 


\section{Conclusion: Utilizing Textiles for Interpretation}

When Mary Dickison stitched a battle flag for her husband, she was proudly displaying her love for her husband as well as support for the Confederate cause. Textile items have the unique capability to illuminate new dimensions of the war. Colonel Stockton, a soldier who fought under the flag, was so moved by its appearance during battle he wrote a poem to honor it. Creating a Confederate flag, and then later putting it away, was an emotional experience for Southern civilians, as it was an emotional experience to receive knit stockings from a wife or sweetheart. Flag presentation ceremonies emphasized once again the importance of a silk battle flag for encouraging patriotism. ${ }^{216}$ Even though Mary Dickison lost her son in the war, she continued to be proud of her contribution to the conflict, the flag her son fought under.

Wearing Southern homespun was another way women could express support for their husbands and the war effort. Homespun fabric also illustrated how Southern society changed during the war. Prior to the war, wearing homespun fabric was not something to be praised, or something to be worn by the upper class. However, the importance of Southern textiles and Southern made goods made the work of domestic spinners and weavers more important. Southern made goods, even if coarser than silk, became fashionable. Women worked to create homespun items for their husbands, and to wear homespun themselves. For unmarried women, wearing homespun was supposed to help them attract a husband or a sweetheart. Women were prompted to stitch for their husbands after hearing cries of inadequate clothing. Many newspaper articles were fairly critical of the government. Oftentimes, the work of women was preferred to the work done by the government. The ideal was that Southern women and their stitching were

\footnotetext{
${ }^{216}$ Wayne K. Durrill, "Ritual, Community and War: Local Flag Presentation Ceremonies and Disunity in the Early Confederacy" Journal of Social History 39, no. 4 (2006): 1107.
} 
superior to any other option. The mourning that women wore for their lost loved ones served as consistent reminders of what was lost during the Civil War. For women who became widows, they wore their mourning for a minimum of three years following the Civil War. The textiles they used to mourn their loved ones for many women represented the loved ones they had lost.

Wartime couples used textiles to illustrate affection and attempt to provide comfort for their spouse in times of scarcity. In the same letter in which T. Taliaferro wrote his wife Hally to describe the clothing he had and to express that he was no longer in need, he also expressed concern over the state of the textiles of his wife, "Could I only know you were we'll off.... Will you not tell your loving husband if you suffer or are in want? That I may leave no stone unturned to add in some way to your comfort. I wish I could come + see for myself, then my mind could be at peace You don't know how I love you... There can be no prouder husband than I." ${ }^{217}$ His wife had written previously that even though many of the "servants" had run away, she still was not forced to resort to doing household duties as she claimed others had to. However, Taliaferro continued to be concerned with how his wife was doing while he was so far away. He wanted to fulfill his masculine duty caring for his wife. His concern illustrates he understand the problems with wartime scarcity so many in the South were suffering from. He also writes words of love to indicate that even in separation his thoughts were still with his wife who had made sure he was well supplied in clothing.

Civil War men and women alike saw stitching as significant work, especially when it was done to support the Southern war effort. Today, historic stitching is often referred to in a derisive manner, in order to indicate a woman's contribution was not significant on a broader scale.

\footnotetext{
${ }^{217}$ Thomas Taliaferro to Harriotte Taliaferro, January 15, 1864, Taliaferro Family Correspondence, Virginia Historical Society.
} 
Textiles grace the pages of diaries and letters frequently, and through textiles historians may study new aspects of their lives. Stitching for many women was the labor they did to clothe themselves and their families, but stitching might also be a pleasant leisure activity. For the women who joined ladies aid societies, an afternoon knitting for the soldiers was a social activity. Newspapers often used the phrase "labor of love" when describing women stitching for their husbands and soldiers. Knitting and stitching was a way women could express their affection. However, in some cases stitching was a political declaration of support, as with homespun and battle flags.

Objects like stockings, battle flags, and fragments of handstitched clothing tell a wider story about who wore the fabric, but also who made the fabric. Tasks, like spinning and weaving, that were largely performed by enslaved people on plantations before the way became the duty of the plantation mistress. Many women of all classes began to perform stitching for wages. Textile represent a drastically changing society during the war, and have applications in emotional, political, and military histories. Textiles have a special ability to allow domestic relations and the relationship between husband and wife to become tangible for museum visitors. ${ }^{218}$

Using objects to teach offers many opportunities for learning as well as immersing museums visitors in the past. Rabinowitz studies the changing life of museums from interpreting only the elite to a more inclusive narrative, and argues that object teaching is a way to make history inclusive. For most women, it was not a leisure activity, but another chore. Rabinowitz describes his experience at Old Sturbridge Village, taking part in the many different heritage crafts performed there. He advocated experiential learning. The knitting, spinning, weaving, and

${ }^{218}$ Richard Rabinowitz, Curating America: Journeys Through the Storyscapes of the American Past, (Chapel Hill: University of North Carolina Press, 2016): 198. 
stitching mentioned in this thesis all offer the opportunity for experiential learning in a wide variety of museums settings. These actions reflect on the lives of women of a variety of social classes, but also of the change that occurred in the war. The physical objects themselves become materializations of the emotional history of the war, but also a gendered history. ${ }^{219}$

The Confederate Flag has been a controversial topic for years. The American public continues to grapple with what place it has in our material culture today. Public historians must decide how to utilize the Confederate flag in museums and public institutions, where some visitors demand to see the flag represented, and others feel uncomfortable by its presence. However, when including items like battle flags in museums, the women who made the battle flags are all too often lost in the narrative. Battle flags represent domestic patriotism, as well as a contribution to the war effort by Southern women. The presence of battle flags on the battlefield reminded the men fighting the war of the women they left behind at home. For unmarried men, the silk battle flags waving on the field represented the Southern ideal: that the bachelor might return home from the war and marry a Southern belle. The flag represented the beginnings of a Southern household in which the male is the head and the lady is a supporting wife. The flags allowed women to participate in and support the conflict, thereby becoming a grand political act for ladies. This dimension adds another way institutions may interpret the war through objects. Typically, the discussion surrounding the flag latching onto military exploits, the lost cause, and racism, as opposed to the women who made silk battle flags. John Coski, in his work The Confederate Battle Flag, acknowledges strong feelings and differing viewpoints that continue to surround the Confederate battle flag today. He argues that the history of the battle flag "reveals the fundamental disagreements among Americans about our past, our present, and

${ }^{219}$ Rabinowitz, 40-45. 
our future." ${ }^{220}$ While this is true, the flag also has the ability to illuminate Confederate history in museums. The flag does not only represent a history of military achievements and failures, and a study of memory and reunions, but also of domestic production and the women who made the silk battle flags many regiments carry. The Confederate flag offers the opportunity to engage with the gendered environment of the Civil War, as well as gendered patriotism. Women and their motives for constructing the flag, are significant to the history of the war. Silk battle flags have broader implications that could be utilized within cultural institutions. While this gendered history does not change the controversy surrounding the flag, it offers a more nuanced interpretation of a controversial object.

Throughout the duration of the war, fabric was constructed and deconstructed. First, fabric was constructed. Women rang in the war with homespun fabrics and silk battle flags in order to support the start of the Confederacy. Second, the war continued longer than many had anticipated, textiles circulated in vast quantities. Women then sent textiles to their husbands to attempt to keep them warm during the winter time. Men also sent fabrics they found and other textile gifts home to their wives. Finally, fabric was deconstructed, as was the fabric of society. Textiles became scarce. Women struggled to continue to supply the textile needs of their husbands and families. Textiles were used to mourn loved ones lost during the conflict. This short foray into the study of textiles and Civil War marriages illustrates further possibilities for interpreting the Civil War using textiles.

${ }^{220}$ John M. Coski, The Confederate Battle Flag: America's Most Embattled Emblem, (Cambridge, MA: Belknap Press of Harvard University Press, 2005): xi. 


\section{BIBLIOGRAPHY}

\section{Articles}

Auslander, Leora. "Beyond Words," The American Historical Review 110, no. 4 (2005).

Cashin, Joan. "Trophies of War: Material Culture in the Civil War Era." Journal of the Civil War Era. 1, no. 3 (2011): 339-367.

Cashin, Joan. "Torn Bonnets and Stolen Silks: Fashion, Gender, Race, and Danger in the Wartime South," vol 61, no. 4 ( 2014): 338-361.

Durrill, Wayne K. 2006. "Ritual, Community and War: Local Flag Presentation Ceremonies and Disunity in the Early Confederacy". Journal of Social History. 39, no. 4 (2006): 1105-1122.

Faust, Drew Gilpin. "Altars of Sacrifice: Confederate Women and the Narratives of War". The Journal of American History. 76, no. 4 (1990): 1200-1228.

Hacker, J. David, Hilde Libra, and Jones James Holland. "The Effect of the Civil War on Southern Marriage Patterns." The Journal of Southern History 76, no. 1 (2010): 39-70.

\section{Books}

Arliskas, Thomas. Cadet Gray \& Butternut Brown: Notes on Confederate Uniforms. Gettysburg: Thomas Publications, 2006

Bachelard, Gaston. The Poetics of Space. Boston: Beacon Press, 1969.

Beckert, Sven. Empire of Cotton: A Global History. Knopf: New York, 2014.

Bernath, Michael T. Confederate Minds: The Struggle for Intellectual Independence in the Civil War South. Chapel Hill: University of North Carolina Press, 2010.

Berry II, Stephen. All that Makes a Man: Love and Ambition in the Civil War South. Oxford: Oxford University Press, 2002.

Bonner, Robert E. Colors and Blood: Flag Passions of the Confederate South. Princeton, N.J.: Princeton University Press, 2002.

Cashin, Joan E. The War was You and Me: Civilians in the American Civil War. Princeton, N.J.: Princeton University Press, 2002.

Clinton, Catherine. The Plantation Mistress: Woman's World in the Old South. New York: Pantheon Books, 1982. 
Coski, John M. The Confederate Battle Flag: America's Most Embattled Emblem. Cambridge, MA: Belknap Press of Harvard University Press, 2005.

Cott, Nancy F. Public Vows: A History of Marriage and the Nation. Cambridge, Mass: Harvard University Press, 2000.

Daly Goggin, Maureen and Beth Fowkes Tobin, Women and the Material Culture of Death. Routledge, 2013.

Denneen Volo, Dorothy and James M. Volo, Daily Life in Civil War America. Westport, Conn: Greenwood Press, 1998.

Faust, Drew Gilpin. Mothers of Invention: Women of the Slaveholding South in the American Civil War. 1st ed. Chapel Hill: University of North Carolina Press, 1995.

Faust, Drew Gilpin. This Republic of Suffering: Death and the American Civil War. New York: Alfred A. Knopf, 2008.

Fox-Genovese, Elizabeth. Within the Plantation Household: Black and White Women of the Old South. Chapel Hill: University of North Carolina Press, 1988.

Lystra, Karen. Searching the Heart: Women, Men, and Romantic Love in Nineteenth-Century America. New York: Oxford University Press, 1992.

MacDonald, Anne. No Idle Hands: The Social History of American Knitting, New York: Ballantine Books, 1988

Mathews, Glenna. Just a Housewife: The Rise and Fall of Domesticity in America. New York: Oxford University Press, 1987.

McCurry, Stephanie. Confederate Reckoning: Power and Politics in the Civil War South. Cambridge: Harvard University Press, 2010.

McPherson, James. For Cause and Comrades: Why Men Fought in the Civil War. New York: Oxford University Press, 1997.

Rabinowitz, Richard. Curating America: Journeys Through the Storyscapes of the American Past. Chapel Hill: University of North Carolina Press, 2016.

Rosenzweig, Roy and David P. Thelen, The Presence of the Past: Popular Uses of History in American Life. New York: Columbia University Press, 1998.

Smith, Mark M. The Smell of Battle, the Taste of Siege: A Sensory History of the Civil War. 
Sullivan, Walter. The War the Women Lived: Female Voices from the Confederate South. Nashville: J.S. Sanders, 1995.

Taylor, Amy Murrell. The Divided Family in Civil War America. Chapel Hill: University of North Carolina Press, 2005.

Thompson Friend, Craig and Lorri Glover, Death and the American South. Cambridge University Press, 2015.

Ulrich, Laurel Thatcher. The Age of Homespun: Objects and Stories in the Creation of an American Myth. New York: Knopf, 2001.

West, Patricia. Domesticating History: The Political Origins of America's House Museums. Washington, DC\& London: Smithsonian Institution Press, 1999.

Wilson, Harold. Confederate Industry: Manufacturers and Quartermasters in the Civil War. Jackson: University Press of Mississippi, 2002.

Zakim, Michael. Ready-Made Democracy: A History of Men's Dress in the American Republic, 17601860. Chicago: University of Chicago Press, 2003.

\section{PUBLISHED PRIMARY SOURCES}

Cary Harrison, Constance. Refugitta Of Richmond: The Wartime Recollections, Grave And Gay, Of Constance Cary Harrison. Knoxville, Tennessee: University Tennessee Press, 2011.

Cheairs Highs, Nathaniel and S. Kittrell Rushing ed. Refugitta Of Richmond: The Wartime Recollections, Grave and Gay, Of Constance Cary Harrison. Knoxville, Tennessee: University Tennessee Press, 2011.

Chestnut, Mary. A Diary from Dixie,. New York: D. Appleton and Company, 1905.

Clay-Clopton, Virginia and Ada Sterling. A Belle of the Fifties: Memoirs of Mrs. Clay of Alabama, Covering Social and Political Life in Washington and the South, 1853-66. Tuscaloosa: University of Alabama Press, 1999.

Dickison, Mary. Dickison and His Men. San Marco Bookstore, 1984.

McGuire, Judith. Diary of a Southern Refugee During the War, by a Lady of Virginia 1867. Lincoln: University of Nebraska Press, 1995.

Nesblett, Elizabeth Scott. A Rebel Wife in Texas. Baton Rouge: Louisiana State University Press, 2001. 
Stephens, Ann. The Ladies Complete Guide to Crochet, Fancy Knitting, and Needle Work. New York: Dick\& Fitzgerald, 1854.

Watkins, Richard and Mary Purnell Dupuy Watkins, and Jeff Toalson. Send Me a Pair of Old Boots \& Kiss My Little Girls: The Civil War Letters of Richard and Mary Watkins, 1861-1865. New York: Universe, 2009.

\section{UNPUBLISHED PRIMARY SOURCES}

The Bond Family Papers. Correspondence of H.L. Bond and Elizabeth Bond. The Virginia Historical Society, Richmond, Virginia.

The Harrison Family Papers. Correspondence of Dr. Jacob Prosser Harrison and Judith Willantina (Temple) Harrison. Correspondence, 1861-1872 . The Virginia Historical Society, Richmond, Virginia.

The Taliaferro Family Papers. Correspondence 1853-1885 Major Thomas Seddon Taliaferro with wife Harriote Hopkins Lee Taliaferro. The Virginia Historical Society, Richmond, Virginia.

\section{NEWSPAPERS}

The Abingdon Virginian, Abingdon, Va.

The Bellevie, Bossier Parish, La.

The Camden Confederate. Camden, SC.

Daily Intelligencer. Wheeling, Va.

The Daily Phoenix, Columbia, SC.

The Eastern Clarion, Paulding Mississippi.

The Evening Star, Washington, D.C.

The Free South. Beaufort South Carolina.

The Morristown Gazette, Morristown, Tn.

New Orleans Daily Crescent. New Orleans, La.

The Richmond Enquirer, Richmond, Va.

The Richmond Times Dispatch, Richmond, Va.

Semi-Weekly Standard, Raleigh, Nc.

The South-Western, Shreveport, La.

Spirit of the Age. Raleigh, North Carolina.

The Staunton Spectator.Staunton, Va. 